\title{
Inequality, credit and financial crises
}

\author{
Cristiano Perugini, Jens Hölscher and Simon Collie*
}

\begin{abstract}
In the three decades leading up to the financial crisis of 2008/09, income inequality rose across much of the developed world. This has led to a vigorous debate as to whether widening inequality was somehow to blame for the crisis by driving private sector credit booms. Despite growing interest, empirical evidence on an inequalityfragility relationship is limited. Based on a panel analysis of 18 OECD (Organisation for Economic Co-operation and Development) countries for the years 1970-2007, this study provides evidence of a positive relationship between income concentration and private sector indebtedness, once other traditional drivers are controlled for. If confirmed, the implications of this result are as follows: (i) the view that the distribution of income is irrelevant to macroeconomic stability, as implicit in mainstream approaches, needs further investigation; and (ii) in order to make the financial system more robust, policy makers should cast the net wider than monetary policy and regulatory reforms and consider the effects of changes to distributive patterns.
\end{abstract}

Key words: Income inequality, Credit booms, Financial crises, Financial deregulation FEL classifications: D31, E51, G01

\section{Introduction}

In the three decades leading up to the financial crisis of $2008 / 09$, economic inequality rose across much of the developed world (Atkinson et al., 2011; OECD, 2011). This rise was nowhere more pronounced than in the USA - the country at the epicentre of the crisis-where, by the mid-2000s, income concentration reached magnitudes not seen since the period immediately preceding the Great Depression. Against this backdrop, a lively debate has re-emerged as to whether inequality may play, directly or indirectly, some destabilising role in the economy.

Central to this debate is the question of whether high or widening inequality contributes to the excessive accumulation of debt, which in turn is widely recognised as being the ultimate driver behind episodes of financial instability. The latter notion can be traced back to Fisher $(1932,1933)$, who argued that 'all great booms and depressions'

Manuscript received 17 November 2013; final version received 22 July 2014.

Address for correspondence: Cristiano Perugini, Department of Economics, University of Perugia (I), Via A. Pascoli 20, 06014 Perugia, Italy; email: cristiano.perugini@unipg.it

* University of Perugia (I), Italy and FREN, Belgrade, Serbia (CP), Bournemouth University, UK $(\mathrm{JH})$ and University of Brighton, UK (SC). The paper was developed with support by the EU-funded Jean Monnet project 'Variety of Institutional Settings and Socio-economic Inequalities in the Process of European Integration', coordinated by Cristiano Perugini. Preliminary versions were presented at conferences and seminars held in Assisi, Belgrade, Bournemouth, Bristol, Glasgow, Kingston, London, Procida, Regensburg, Seoul, Tallinn and Warsaw. All comments received are gratefully acknowledged. We are also grateful to Francesco Venturini (University of Perugia) for assistance on econometric aspects.

(C) The Author 2015. Published by Oxford University Press on behalf of the Cambridge Political Economy Society. All rights reserved. 


\section{Page 2 of 31 C. Perugini, J. Hölscher and S. Collie}

are ultimately caused by two dominant factors, 'namely, over indebtedness to start with and deflation following soon after' (Fisher, 1933, p. 341). Building on this view, Minsky $(1975,1982,1986)$ placed rising debt at the heart of his financial instability hypothesis, although admittedly his focus was on corporate debt and investment, rather than household debt and consumption. He argued that an inherent feature of capitalist economies is the propensity for the financial system to swing between periods of extreme robustness and extreme fragility. Paradoxically, it is the environment of economic prosperity and stability itself that shows the seeds of the ensuing financial collapse. During prosperous times, when corporate incomes are high, a speculative euphoria develops and lending surpasses what borrowers can possibly repay from future incoming cash flows. The eventual result is widespread default, shortly followed by a liquidity crisis and asset price deflation. Lending contracts sharply and even those businesses that are creditworthy are denied access to finance, leading to a contraction in the real economy.

Kindleberger (1978) tells a similar story, in which a benign economic environment creates a sense of optimism for the future. As a result, asset prices rise, leading to yet further optimism. Key to this narrative is investors' use of credit to gain increased exposure to rising asset prices, driving prices up further. A self-reinforcing mania develops and profit expectations depart significantly from their fundamental potential, and all the while debt-to-income ratios rise and capital ratios fall. The crisis reveals itself when something occurs to expose the true extent of this overoptimism and a panic ensues. Asset prices crash as investors rush to liquidate their positions at the same time.

A substantial body of empirical research, mostly developed in the last decade, has confirmed that episodes of financial instability are indeed precipitated by excessive levels of debt in some form or another (see, e.g., Borio and White, 2003; Mendoza and Terrones, 2008; Elekdag and Wu, 2011; Reinhart and Rogoff, 2008; Schularick and Taylor, 2012).

Accordingly, the investigation of the roots of financial instability needs to focus on the drivers of credit/debt expansion. The existing body of theories (for a review see Mendoza and Terrones, 2008) provides explanations related to the following: herd behaviour by banks (Kindleberger, 1978); information problems that lead to bankinterdependent lending policies (Rajan, 1994); the underestimation of risks (Borio et al., 2001) and the loosening of lending standards (Dell'Ariccia and Marquez, 2006); the presence of government guarantees (Corsetti et al., 1999); limited commitment on the part of borrowers (Lorenzoni, 2005); and business cycles and financial accelerators (see, e.g., Bernanke et al., 1999; Kiyotaki and Moore, 1997). On the empirical side, the factors established as being key drivers of credit expansion include deregulation of the financial system (Demirguc-Kunt and Detragiache, 1998; Kaminsky and Reinhart, 1999; Rancière et al., 2006); accommodative monetary policy (Borio and White, 2003; Elekdag and Wu, 2011; Mendoza and Terrones, 2008); rapid economic growth (Mendoza and Terrones, 2008); and inflows of foreign capital (Elekdag and Wu, 2011; Decressin and Terrones, 2011). The key question that this paper seeks to address is whether the redistribution of income should also be added to this list.

Despite growing interest and theoretical debate on the inequality-credit-crisis relationship (see Section 2), the empirical research is still limited. The purpose of this paper is to add to this scarce evidence with an empirical model derived from a critical discussion of the existing literature. We are able to present the results of an econometric analysis for a panel of 18 Organisation for Economic Co-operation and Development (OECD) developed economies over the period 1970-2007, which 
shows a statistically significant, direct, positive relationship between income concentration and private sector indebtedness when controlling for other traditional, structural credit determinants. In the same sample, growing private sector indebtedness is shown, as a preliminary exercise, to increase the probability of a financial crisis.

The contribution of the paper to existing knowledge is twofold. On the conceptual side, besides providing a thorough review and discussion of the existing literature on the topic, we provide an organised view of the channels through which widening inequality can favour credit expansion. On the empirical side, we complement the only crosscountry evidence so far available - see Bordo and Meissner (2012) (hereafter Bordo and Meissner, 2012) which is our main empirical inspiration and which concluded for the inexistence of an inequality-credit nexus. By using a somewhat different approach, which we regard preferable in many respects, we reach the opposite conclusion, hence showing that their evidence cannot be considered as conclusive. In particular, we depart from this reference work regarding the following: (i) the choice of the measure of credit (a broader, more inclusive metric); (ii) the estimation of the model in levels rather than in changes; (iii) the explicit consideration of the threats posed by endogeneity and reverse causation issues; (iv) the explicit consideration of the institutional drivers of credit expansion (financial markets deregulation); and (v) the consequent restriction of the time span of the analysis to the last four decades, but with the addition of four countries. Our more limited time coverage is, however, not to be regarded as a major drawback, since it corresponds to the period in which credit started to remarkably decouple from broad money as a result of increased leverage and augmented funding via the non-monetary liabilities of banks. A period in which most developed economies entered an age of unprecedented financial innovation, risk and leverage, which eventually undermined their stability (Schularick and Taylor, 2012).

The remainder of this paper is structured as follows. Section 2 reviews the literature on inequality, credit and financial fragility and provides the conceptual background on which our empirical model relies. Section 3 describes the data, provides some preliminary descriptive evidence and presents the methodology and the findings of the econometric model. Section 4 concludes.

\section{Inequality, indebtedness and crisis: theoretical explanations and empirical evidence}

A vast literature exists that seeks to determine the sources of observed changes in the income distribution over the last four decades and a comprehensive review of this literature is beyond the scope of this paper. Instead, what follows in the next few paragraphs is a brief summary of some of the key themes to provide the reader with a rudimentary context for subsequent discussion.

Increasing trends of inequality have been explained by changes in taxation that reduced progressivity of the tax schedule at the top of the distribution (see, e.g., Atkinson et al., 2011), globalisation and technical change that increased relative skill premia (see, e.g., Van Reenen, 2011). Other labour market arguments include the spread of performance-related pay (Lemieux, 2006; Lemieux et al., 2009), changing labour market institutions such as the decline of unionisation and minimum wages (Card et al., 2004; Card and Di Nardo, 2002) and the rise of superstars (Rosen, 1981). Overall, these theories conclude for low-wage positions being associated with low-skilled or low-educated workers and higher earnings to the highly educated/skilled labour supply. In particular, 


\section{Page 4 of $31 \quad$ C. Perugini, J. Hölscher and S. Collie}

the skill-biased technical change (SBTC) hypothesis has complemented the predictions of the human capital (Becker, 1964) and the signalling/screening (Spence, 1974; Weiss, 1995) theories, by maintaining that the introduction of new technologies and the consequent organisational innovation would increase relative demand for skilled (in the sense of educated) workers, pushing their relative returns upwards (Autor and Katz, 1999).

In a similar demand/supply framework, others blame globalisation (for a review see Chusseau et al., 2008). In a standard neoclassical Stolper-Samuelson framework, trade with countries with lower ratios of high-skilled to low-skilled workers increases the demand for high-skilled labour, thus pushing up the skill premium. Similar consequences are predicted by the new trade theories (see, e.g., Feenstra and Hanson, 1996), in which outsourcing patterns increase the relative demand of skilled labour, and hence wage inequality, in both origin and destination countries. Trade theories developed in the framework of the new economic geography contribute to explain inequality within countries due to specialisation patterns driven by the existence of agglomeration economies, which originate well-known core-periphery patterns (see Fallah and Partridge, 2006; Fujita et al., 1999). Lastly, in the recent literature on firm heterogeneity and international trade, and despite theoretical models based on uniformity of wages (Melitz, 2008), the empirical evidence shows that internationalised firms tend to have higher productivity and pay higher wages (see Serti et al., 2010; Castellani et al., 2010). This contributes to explain the observed within-industry variability in wages.

The limited capacity of these theories to explain observed inequality and labour market patterns, particularly job polarisation (Goos and Manning, 2007), has led to a more nuanced formulation of the SBTC theory. The main explanation relies on the so-called routinisation hypothesis (Autor et al., 2003): only routine manual and cognitive tasks, placed at the middle of the wage distribution, can be easily replaced by computers. As a consequence, routine workers will worsen their wage position both relative to abstract workers and to elementary non-routine occupations.

Finally, somehow as an antithesis for the preceding explanations, Galbraith (2007, 2012) argues that observed income inequality trends are so similar across countries and over time that they cannot be accurately explained by micro, country-specific factors. Instead Galbraith suggests that within-country (and between-country) income inequality trends have been driven largely by macro, global forces, which all countries respond to- - he cites changes to the global financial architecture, including the deregulation and globalisation of finance, as the primary cause.

The notion that inequality may be linked to economic instability is not new. Writing on the causes of the Great Crash of 1929 and the ensuing Great Depression, Marriner Eccles, chairman of the Federal Reserve during that period, argued that:

a giant suction pump had by 1929-1930 drawn into a few hands an increasing portion of currently produced wealth. This served them as capital accumulations. But by taking purchasing power out of the hands of mass consumers, the savers denied themselves the kind of effective demand for their products that would justify a reinvestment of their capital accumulations in new plants. In consequence, as in a poker game where the chips were concentrated in fewer and fewer hands, the other fellows could stay in the game only by borrowing. When their credit ran out, the game stopped. (Eccles, 1951, p. 76, cited in Reich, 2010)

John K. Galbraith (1992 [1954], p. 97) argued in similar vein, highlighting the 'bad distribution of income' as being the first of 'five weaknesses [that] seem to have had an especially intimate bearing on the ensuing disaster'.

Following the onset of the global financial crisis of 2008-09, interest in this notion has been rekindled, with a number of analyses suggesting that widening inequality may have 
played a key role in the recent crisis. These include a number of popular books (see, e.g., Rajan, 2010; Reich, 2010; Galbraith, 2012; Stiglitz, 2012; Palley, 2012), policy-focused papers (see, e.g., Stiglitz, 2009; IMF-ILO, 2010; Krueger, 2012) and opinion editorials penned by prominent economic commentators (see, e.g., Milanovic, 2009; Wade, 2010; Roubini, 2011). In addition to these contributions there is also a small (but growing) body of academic research that has attempted to more formally analyse the relationship empirically and theoretically (see, e.g., Atkinson and Morelli, 2010, 2011; Kumhof and Rancière, 2010; Fitoussi and Saraceno, 2011; Kumhof et al., 2012; Tridico, 2012; Bordo and Meissner, 2012; Van Treek, 2014).

Rajan's book Fault Lines (Rajan, 2010) contributed much of the momentum to the current debate. He argues that rising inequality in the USA pressured governments of all political persuasions to enact policies aimed at improving the situation of those low- and middle-income voters being left behind. However, in the polarised world of American politics, the usual recourse of governments - the redistribution of income via taxes and social spending - was politically toxic. Instead successive governments chose to placate those voters by enacting policies that would expand their access to credit, such as deregulation of credit markets and encouraging of state-owned mortgage agencies to expand lending to low-income households. This created a glut of credit, which households obligingly guzzled as a substitute for rising incomes as they sought to attain the standard of living they had come to expect. The resulting credit bubble laid the foundations for the subsequent crisis.

Acemoglu (2011) suggests that this explanation may misinterpret the true causeeffect relationship. He posits an alternative hypothesis whereby it was politics that drove both inequality and the financial crisis. There is concomitance, not causation. Citing evidence from Bartels (2008) and Gilens (2005), Acemoglu argues that the policies over the period in question were in fact more closely aligned to the preferences of a minority of high-income voters; instead of redistributive policies favouring low- and middleincome constituents, politicians implemented financial deregulation policies favouring influential high-income constituents (many of whom worked in, or directly benefited from, the financial sector). Yet Acemoglu does not link rising income concentrations to increased political influence amongst the affluent, despite this being a central tenet of Bartels's study (Bartels, 2008) (on which his argument is founded). With the addition of this component, inequality may once more be seen to lead to increased financial instability through a feedback process: (i) rising inequality leads to increased political influence amongst the wealthy; (ii) this is used to promote policies of financial market deregulation; (iii) this leads to both financial instability and rising inequality; and back to (i). The possibility of higher income concentrations affording those at the top of the distribution greater political influence with which to promote policies of financial deregulation in the pursuit of personal interest is something explored by Krugman (2012). The key difference between Acemoglu's hypothesis and Rajan's hypothesis, then, is the tail of the distribution from which deregulatory pressure comes.

The above narratives are specific to the US social and political context. Others suggest that a relationship between income inequality and financial instability may apply more generally across countries. In a far-reaching study on the nature and causes of income inequality drawing on the University of Texas Income Project dataset, Galbraith (2012) finds that income inequality and financial fragility rose in tandem across the developed world from the 1970s onwards, as a result of changes in the global financial architecture. He suggests that the two are related in some cause-effect way, noting that 'the link, of course, runs through debt' (Galbraith, 2012, p. 3). 


\section{Page 6 of 31 C. Perugini, J. Hölscher and S. Collie}

In the spirit of Kalecki (1942) and Kaldor (1955), Stiglitz (2009 2012) and Fitoussi and Saraceno (2010 2011) argue that rising income inequality in the run-up to the crisis redistributed income from households with a high propensity to consume to those with a low propensity to consume, weighing on consumption expenditure and suppressing aggregate demand. The policy response from modern inflation/output-targeting central banks was to loosen monetary conditions to support demand. This propped up consumption for a while, but it could not go on forever; private sector debt eventually reached unsustainable levels and the credit bubble burst. Adding strength to this underconsumption argument is the empirical evidence on the positive relationship between relative income and the marginal propensity to save (see, e.g., Dynan et al., 2004).

All preceding explanations are political economy ones, in the sense that, in certain institutional settings, high levels of inequality provoke a political or monetary response, which is then responsible for the expansion of credit, the excessive build up of debt and the corresponding financial instability. Although intellectually appealing, these approaches appear of limited explanatory power, since policy actions are always the outcome of a convergence of economic, political and social forces; reducing them to be primarily driven by inequality patterns seems therefore an oversimplification.

An alternative view is that a more direct link between inequality and indebtedness (and hence risk of crisis) exists, i.e. one that does not rely on specific institutional/policy arrangements and so holds in a more general sense. Taking a more formal approach than those discussed above, Kumhof and Rancière (2010) develop a closed-economy dynamic stochastic general equilibrium model in which a financial crisis is the endogenous result of rising income inequality. They take as stylised facts the correlation between rising income inequality and credit growth in the USA, in both the periods preceding the 1929 market crash and in the run-up to the recent financial crisis. When the model is calibrated to US data, simulations show how increased income inequality can endogenously lead to credit growth, higher leverage and increased probability of a financial crisis. The model has at its heart two classes of economic agent: investors (defined as the top $5 \%$ of earners) who own all of the capital, earn only capital income and save and invest as well as consume; and workers (everyone else) who earn only wage income and use this only for consumption. A key assumption is that workers have some minimal consumption level that they must attain, which is a function of some previously attained level of consumption, and that they will turn to credit markets (which are assumed to be perfect) if necessary in order to attain this. When a shock reduces the bargaining power of workers relative to investors, the workers, faced with declining real wage growth, borrow in order maintain their desired level of consumption. On the other side of the transaction, investors lend to the workers out of their rising incomes via financial intermediaries, which they own. As inequality increases, workers become increasingly indebted to investors, who amass claims on them. The saving and borrowing behaviour of these two groups leads to increased demand for financial intermediation and the size of the financial sector grows in relation to the rest of the economy. All the while, leverage of the household and financial sector increases, thus increasing the probability of a financial crisis. A key feature of this model is that consumption inequality rises much more slowly than income inequality due to the substitution of loans for income at the bottom of the distribution. This is consistent with documented trends concerning the relative evolution of income and consumption inequalities in the USA and elsewhere in the run-up to the recent crisis (e.g. for the USA see Krueger and Perri, 
2006; for the UK see Blundell and Etheridge, 2010; for Canada see Brzozowski et al., 2010; and for Italy see Jappelli and Pistaferri, 2009).

Such a transmission mechanism, from increasing income concentration at the top of the distribution to increased availability of household credit, is also proposed by Fitoussi and Saraceno (2010, 2011) and Milanovic (2009). The latter argues that rising inequality in the USA led to vast accumulations of wealth at the top of the income distribution, which led to a glut of funds seeking profitable investment. The financial sector, overwhelmed by the volume of funds seeking investment relative to profitable opportunities in the productive sector, became increasingly more inventive and reckless, 'basically throwing money at anyone who would take it' (Milanovic, 2010, p. 194).

On the demand side, higher inequality causes worse-off agents to borrow more in order to maintain consumption expenditure as their income falls. This finding is consistent with previous USA-based studies on the relationship between income inequality and household debt by Iacoviello (2008), Blundell et al. (2008) and Krueger and Perri (2006).

However a key point of contention is the extent to which observed increases in measured income inequality reflect widening dispersion of permanent income or of transitory income, since only the latter should lead to higher borrowing in the context of permanent-income and life-cycle theories (Friedman, 1957; Modigliani and Brumberg, 1954). Yet in Kumhof and Rancière's model (2010), households at the bottom of the income distribution borrow to maintain consumption after a shock affects the distribution of permanent income. What is more, empirical evidence suggests that the rise in inequality observed in recent decades was driven overwhelmingly by increased dispersion in permanent income (see, e.g., Kopczuk et al., 2010; Debacker et al., 2013).

Van Treek (2014, p. 10) argues that in order to properly understand the effects of the distribution of permanent income on consumption and savings decisions, the permanent-income hypothesis must be abandoned in favour of the lesser-known relative income hypothesis, originally formulated by Duesenberry (1949). This hypothesis posits that a household's consumption expenditure in a given period is a function of some previously attained maximum level of consumption expenditure and of the consumption expenditure of reference households. The latter channel is emphasised by Frank et al. (2010), who build a theoretical model of consumer behaviour with the concept of relativity of consumption at its very foundations. They argue that rising inequality leads to expenditure cascades, 'whereby increased expenditure by some people leads others just below them on the income scale to spend more as well, in turn leading others just below the second group to spend more, and so on' (Frank et al. 2010, p. 5). In support of this hypothesis, they present empirical evidence of a positive relationship between the level of income inequality and financial distress in the 100 most densely populated US counties. Similarly, Bertrand and Morse (2013) find that the consumption expenditure and income of rich households within each US state is a significant predictor of the consumption expenditure of non-rich households within that state, holding the income of those middle-income households constant.

Whilst theoretical explanations of an inequality-crisis relationship abound, empirical evidence on the relationship is limited. Kumhof et al. (2012) build on Kumhof and Rancière (2010) by opening up the model to the international sector. Calibrating the model to UK data, simulations show that increased inequality endogenously leads to credit expansion, increased leverage and increased current account deficits, which in turn increase the probability of a systemic financial crisis. As a complement to this 


\section{Page 8 of $31 \quad$ C. Perugini, J. Hölscher and S. Collie}

theoretical model, Kumhof and coauthors also conduct an econometric analysis using a panel of 18 OECD countries over the period 1968-2006. They find that income concentration (measured by the top $1 \%$ and top $5 \%$ income shares) is a statistically significant predictor of external deficits through the channels just described.

Using data from 25 countries over the period 1911-2010, Atkinson and Morelli (2010, 2011) look for patterns of rising inequality in advance of 'systemic' banking crises. Consistent with Rajan's hypothesis, they find significant increases in income inequality in the USA prior to both the 1929 crash and the recent financial crisis. However they find that this pattern is far from universal. They also stress that their methodology focuses solely on changes in inequality and so is silent about the effect of levels of inequality on financial fragility, an avenue they highlight for further research and which we follow here.

Another study that contests the universality of a link between income inequality and crises is that of Bordo and Meissner (2012). Based on a panel of 14 mainly advanced countries from 1920 to 2008, they first find a statistically significant, positive relationship between credit growth and the occurrence of a financial crisis. In the second stage of their research, they investigate econometrically the link between changes in the top $1 \%$ income share and changes in annual bank lending, finding no statistically significant relationship between the two. On this basis they reject what they call the 'RKR' (Rajan, Kumhof and Rancière) hypothesis, in favour of the more traditional determinants of credit growth and crises.

\section{Inequality, deregulation and credit: empirical analysis}

The variety of possible interpretative frameworks just summarised suggests different reasons underpinning the cause-effect relations between inequality, policy variables, indebtedness and the outburst of a crisis. Consistent with the most general explanations of the inequality-credit growth link, our objective here is to look for empirical evidence on the existence of a direct relationship between income inequality and the size of credit once other possible drivers, including deregulation of financial markets, are accounted for. Our approach shares many similarities with Bordo and Meissner's (2012) study; however, it significantly departs from it in terms of methodology, time/country coverage and variables used.

Our research objective poses several issues on both the empirical side and the econometric side. First of all, as usual when dealing with inequality in a panel dimension, gathering the information needed for the dataset is a challenging task. Our dataset covers 18 OECD countries over the period 1970-2007. Compared with B\&M's study, we therefore have more cross-country observations ${ }^{1}$ but a shorter time dimension. This assures higher comparability/homogeneity of data and better availability of explanatory variables, while allowing us to focus on the period in which income inequality, deregulation and household indebtedness rose in tandem across much of the developed world. This entails giving up a longer-run perspective, which, however, (i) would have been based on fragmentary and heterogeneous empirical materials and (ii) would not have been able to consider the role of major institutional changes on the side of financial markets (which B\&M ignore) due to lack of data before the 1970s.

\footnotetext{
${ }^{1}$ To the 14 countries considered by Bordo and Meissner (2012) (Australia, Canada, Denmark, France, Germany, Italy, Japan, the Netherlands, Norway, Spain, Sweden, Switzerland, the UK and the USA), we add Portugal, Finland, Ireland and New Zealand.
} 
A second major point to be clarified and dealt with in Section 3.1 is that a credit expansion, although regularly preceding and determining the conditions of a financial crisis, is not per se necessarily negative for the economy when it is driven by factors related to the real economy or to the normal development of macroeconomic aggregates. For this reason we need to analyse the relationships of interest in the framework of a more general model of credit drivers, derived on the basis of the relevant literature. A third group of problems that need to be addressed, dealt with in Section 3.3, relates to the complexity of the relationships among the variables considered, which are far from being univocally determined. On the one side, a typical problem of endogeneity related to potential reverse causality exists between credit growth and the factors employed as its drivers. On the other side, the explanatory variables of main interest here might not be independent of each other. Rather, a causal link has been hypothesised both from inequality to deregulation (as in Rajan's explanations) and vice versa (as in Acemoglu's view); similarly, rising inequality could drive monetary policy (Stiglitz's hypothesis), which also needs to be included in the set of regressors. All these aspects are accounted for by proper econometric treatments, namely by means of instrumental variable (IV) approaches. On the descriptive side, the direction of causality has been preliminarily tested using a Granger analysis (Granger, 1969).

The remainder of this section goes on to discuss the data (Section 3.1) before presenting some preliminary descriptive evidence (Section 3.2), the econometric methods (Section 3.3) and our findings (Section 3.4).

\subsection{Data and variables}

The measure of credit that we use in all our specifications is the level of domestic credit to the private sector as a percentage of GDP, from the World Development Indicators database (World Bank, 2012). This indicator is used as the dependent variable in the estimation of the effects of inequality and deregulation of financial markets on credit expansion (see Section 3.3). The same variable is also used as a predictor of financial crises in the preliminary descriptive exercise carried out in Section 3.2. The indicator includes credit to individuals and enterprises from banks and other financial corporations, which, according to the definition of the variable provided in the World Development Indicators, include finance and leasing companies, money lenders, insurance corporations, pension funds and foreign exchange companies. This is in contrast to B\&M, who use the log of real bank loans to the private sector. As maintained by Elekdag and Wu (2011), a credit aggregate that also includes credit extended by non-deposit-taking institutions is preferable, as credit booms can arise owing to funds provided by these agents, especially in periods of high rates of financial innovation and deregulation, as in the one under scrutiny here. Our choice to look at the amount of total credit (as a percentage of GDP) in levels, rather than in terms of changes (as in B\&M), is motivated by the fact that all the literature emphasises how it is excessive levels of credit in an economy that leads to financial crisis, not necessarily the rate at which it grows: whether higher rates of credit growth lead to a financial crisis depends on the initial level of credit available in the economy, since the same growth rate might translate into very different levels of credit and risk. Also, increasing levels of credit do not necessarily lead to instability per se: other things being equal, credit growth accompanied by similar income/productivity growth need not entail increased macroeconomic risk; similarly, unchanged debt levels may involve increased macroeconomic risk if income/productivity is falling. This 


\section{Page 10 of 31 C. Perugini, J. Hölscher and S. Collie}

is another benefit of using credit as a percentage of GDP (and we also control for per capita GDP, as discussed below).

There is one important limitation, common to both of the credit measures discussed above. This is the fact that they comprise household debt (in which we are interested) and the debt of businesses and other private organisations. Unfortunately, comparable measures of household debt/credit exclusively are not available for the time and geographical coverage of our study. To overcome this, as per B\&M, a measure of gross fixed capital formation as a percentage of GDP is also included in all regressions to account for credit extended to the non-household private sector. Despite considering this variable a reasonably reliable proxy for the most part of credit demanded by firms for investment purposes, we are aware of its imperfection; for example, retained profits can also be used for investment financing. Unfortunately, a variable that allows us to control for this source of financing more specifically is not available for the countries and time period covered here. The inclusion of GDP growth also serves as an additional control for credit demand for firms' investment purposes, driven by expectations on future levels of aggregate demand. Lastly, a similar role is played by the inclusion of a measure of portfolio investment (as a percentage of GDP), in order to control for credit demand driven by transactions in equity and debt securities.

As a proxy for income concentration and inequality more generally, we follow B\&M in using the share of total income going to the top $1 \%$ of earners, from the World Top Incomes Database. Robustness checks are then implemented using the top 5\% and the top $10 \%$ shares. These data have been obtained from historical income tax records by several different teams of researchers following the methodology of Piketty (2001). Observation units are individuals, households or tax units and income includes labour, business and capital income (in some cases also realised capital gains). As a result there are some cross-country comparability issues (although small), which may also happen over time due to changes in tax legislation (see Atkinson et al., 2011). Another conceptual shortcoming of this indicator is that the income concept is market income (i.e. pre-tax and transfers), whereas in this context it would be preferable to use disposable income, which bears more significantly on household/individual consumption, investment and borrowing decisions. However, this indicator provides an excellent insight into income concentration at the top of the distribution and it is particularly suitable to represent the side of inequality we consider important here, related to the ideas of relative income and consumption cascade effects as drivers of credit expansion. By its own nature, it offers little information as to what is happening at the bottom of the distribution. However, the shortcoming of offering a partial view on the distribution is common to all measures of inequality and empirical evidence shows top income shares to be strongly correlated with broader inequality measures, such as the Gini coefficient (see, e.g., Leigh, 2007). Lastly, these indicators also guarantee greater coverage and comparability across countries and over time as well as consistency vis-à-vis the existing inequality-crisis literature (Bordo and Meissner, 2012; Kumhof et al., 2012).

The third key variable of our analysis is the indicator of credit market (de)regulation (code 5A) supplied by the Fraser Institute in the Economic Freedom of the World database (Gwartney et al., 2010). The measure, ranging from 0 to 10 in ascending order of deregulation, is a summary indicator of four dimensions related to the following: (i) ownership of banks; (ii) foreign bank competition; (iii) private sector credit; and (iv) interest rate controls/negative interest rates. The summary indicators has been extensively used in the existing empirical literature (see, e.g., Giannone et al., 2011; 
Dawson, 2006; Stankov, 2012); the alternative credit market regulation index by Abiad et al. (2008), also widely employed (see, e.g., Mendoza and Terrones, 2008; Azzimonti et al., 2012), is more limited over time (1973-2005) and would remarkably reduce the number of observations, especially in the most recent years, which are of great interest here. An extensive literature has emphasised that deregulation of financial markets triggers credit expansion, for example due to increased aggregate supply of financial instruments and credit (Bordo and Meissner, 2012), the consequences of increased competition (Gosh, 2010; Dell'Ariccia and Marquez, 2006), the emergence of implicit guarantees (Gourinchas et al., 2001; Corsetti et al., 1999) and the increase in opportunistic behaviours by bankers (Demirguc-Kunt and Detragiache, 1998).

As already mentioned, also on the basis of the existing literature, we include among the regressors a measure of portfolio investments (as a percentage of GDP) to control for credit demand driven by transactions in equity and debt securities, including external liabilities (except those constituting foreign authorities' reserves). This variable also accounts for financial capital inflows usually considered in the literature as related to credit growth (Mendoza and Terrones, 2008; Elekdag and Wu, 2011). An alternative variable for this purpose would have been a measure of the current account balance (as a percentage of GDP), but when employed in our estimates this did not show itself to be significant and so was excluded for the sake of model parsimony. Two other variables, the real interest rate (lending rate adjusted by the GDP deflator) and the broad money supply (M2-to-GDP ratio), act as proxies for the monetary policy environment. ${ }^{2}$ As emphasised by Elekdag and Wu (2011, p. 9), the interest rate alone may not be able to accurately represent the level of global liquidity at all times, especially more recently due to non-conventional monetary policies. The use of a lending rate (in the place of a policy rate) allows for the complexity of institutional arrangements in the financial markets that shape cross-country differences in interest rate pass-through effects (see, e.g., European Central Bank, 2009; Cottarelli and Kourelis, 1994). In the use of a broad concept of money supply, we follow Schularick and Taylor (2012). All the variables just described are from the World Bank's World Development Indicators database.

Many studies find that the overall level of economic development, measured by per capita income or income growth measures, is the strongest predictor of financial progress and credit availability (see, e.g., Adarov and Tchaidze, 2011 and the many references cited therein). We therefore include among the regressors the level of real per capita GDP and the annual GDP growth rate (both from Historical Statistics of the World Economy: 1-2008 AD, copyright Angus Maddison), which also act as further controls for the procyclicality of credit (Borio et al., 2001). Strictly speaking, this is already accounted for by standardising the amount of credit to GDP ratio; however, as emphasised by Mendoza and Terrones (2008), this measure can ambiguously represent credit expansion, since its growth might be simply due to a GDP decline, with credit being constant. Including controls for GDP level and growth contributes to address this issue.

It is worth remembering that in studies with such an extensive time and geographical coverage, the use of second-best variables is the norm, due to scanty availability of consistent and 'ideal' information over time and space. This caveat should always be kept in mind when interpreting and generalising the outcomes obtained. Fortunately, as

\footnotetext{
${ }^{2}$ An alternative, indirect approach was to include variables emphasising the role of monetary stabilisation programmes, such as the rate of inflation or a real exchange rate (Gourinchas et al., 2001). These two variables, included in the model, did not show significance and were excluded due to the multicollinearity problems they generated.
} 


\section{Page 12 of $31 \quad$ C. Perugini, J. Hölscher and S. Collie}

explained extensively later, proper econometric methods allow us to effectively address these issues. In particular, the panel data estimation techniques used here, by means of fixed country and time effects, allow us to control for unobserved and imperfectly measured factors specific to countries and years, rendering the estimation of the coefficients of core interest reasonably reliable.

\subsection{Preliminary and descriptive evidence}

As a preliminary step prior to the main empirical model, we provide evidence on the link between credit expansion and periods of financial crisis. Although credit expansion might be due to financial deepening shown to support growth (Levine, 2005) or normal cyclical upswings, credit booms are typically associated with growing financial imbalances and tend to end abruptly, often in the form of financial crises (Elekdag and Wu, 2011). As emphasised in the previous sections, an extensive literature agrees on the existence of this relationship, which is largely confirmed empirically. Following Bordo and Meissner (2012) and Schularick and Taylor (2012), we explore whether this relationship also exists in our database by estimating the probability of a banking crisis as a function of credit available in the economy, in the following form:

$$
\operatorname{Pr}\left(\text { bankingcrisis }_{i, t}\right)=f\left(\text { Cred }_{i, t}+\alpha_{i}+\tau_{t}+\varepsilon_{i, t}\right)
$$

where subscripts $i$ and $t$ refer to countries and years, respectively $(i=1, \ldots, 18 ; t=1970$, $\ldots, 2010) ; \alpha_{i}$ and $\tau_{t}$ are the country- and the time-specific effects and $\varepsilon_{i, t}$ is an idiosyncratic error term for each country and each period. The dependent variable is coded as a binary indicator equal to 1 when a banking crisis occurred according to Laeven and Valencia (2013) and 0 otherwise. The use of binary variables is customary in this kind of estimation and is due to poor availability (over time and space) of continuous variables able to properly describe a financial/banking crisis. Also, the expansion of a financial aggregate (e.g. stock exchange or liquidity) does not necessarily lead to a crisis. Laeven and Valencia (2013) define a banking crisis as an event that meets two conditions: (i) significant signs of financial distress in the banking system (as indicated by significant bank runs, losses in the banking system and/or bank liquidations); and (ii) significant banking policy intervention measures in response to significant losses in the banking system. This definition and other methodological aspects, including various robustness checks, detailed in the paper assure high reliability of the information included in the database.

The explanatory variable Cred is the amount of credit to GDP ratio as described in the previous sections. Results presented in Table 1 confirm the existence of a strong, positive, statistically significant and robust relationship between the amount of credit available as a percentage of GDP, and the probability of a banking crisis.

The plots reported in Figure 1 support the existence of the relationship for a selection of countries in which the link is particularly clear-cut (the dotted vertical lines identify banking crises). Overall, this empirical evidence indicates that, as done in the antecedent literature, we can now focus on the fundamental drivers of credit expansion, particularly those of interest to us.

Table 2 provides basic descriptive statistics on the variables used in the empirical model, showing that they provide substantial levels of variability. As expected, data availability on inequality poses the most severe constraint to the analysis. (see Table 3) A 
Table 1. Banking crisis and credit, 1970-2010

\begin{tabular}{|c|c|c|c|c|}
\hline $\begin{array}{l}\text { Dependent variable: } \\
\text { banking crisis }\end{array}$ & Logit; RE (1) & Logit; RE (2) & Logit; FE (3) & Logit; FE (4 \\
\hline cred_GDP & $\begin{array}{l}0.034^{\star \star \star} \\
(7.12)\end{array}$ & $\begin{array}{l}0.036^{\star \star \star} \\
(3.80)\end{array}$ & $\begin{array}{l}0.040^{\star \star \star} \\
(7.42)\end{array}$ & $\begin{array}{l}0.046^{\star \star \star} \\
(3.86)\end{array}$ \\
\hline Constant & $\begin{array}{l}-6.489^{\star \star \star} \\
(-8.80)\end{array}$ & $\begin{array}{l}-28.714 \\
(-0.00)\end{array}$ & $\begin{array}{l}- \\
-\end{array}$ & - \\
\hline Time dummies & No & Yes & No & Yes \\
\hline Wald test $(\mathrm{RE}) / \mathrm{LR}$ test (FE) & $50.73^{\star \star \star}$ & - & $103.80^{\star \star \star}$ & $213.27^{\star \star \star}$ \\
\hline$N$ observations & 719 & 719 & 599 & 599 \\
\hline
\end{tabular}

Notes: The dependent variable is a dummy equal to 1 when a banking crisis occurred according to Laeven and Valencia (2013).

$Z$-statistics are based on robust standard errors and reported in brackets.

${ }^{\star} p<0.10,{ }^{\star \star} p<0.5$ and ${ }^{\star \star \star} p<0.01$.
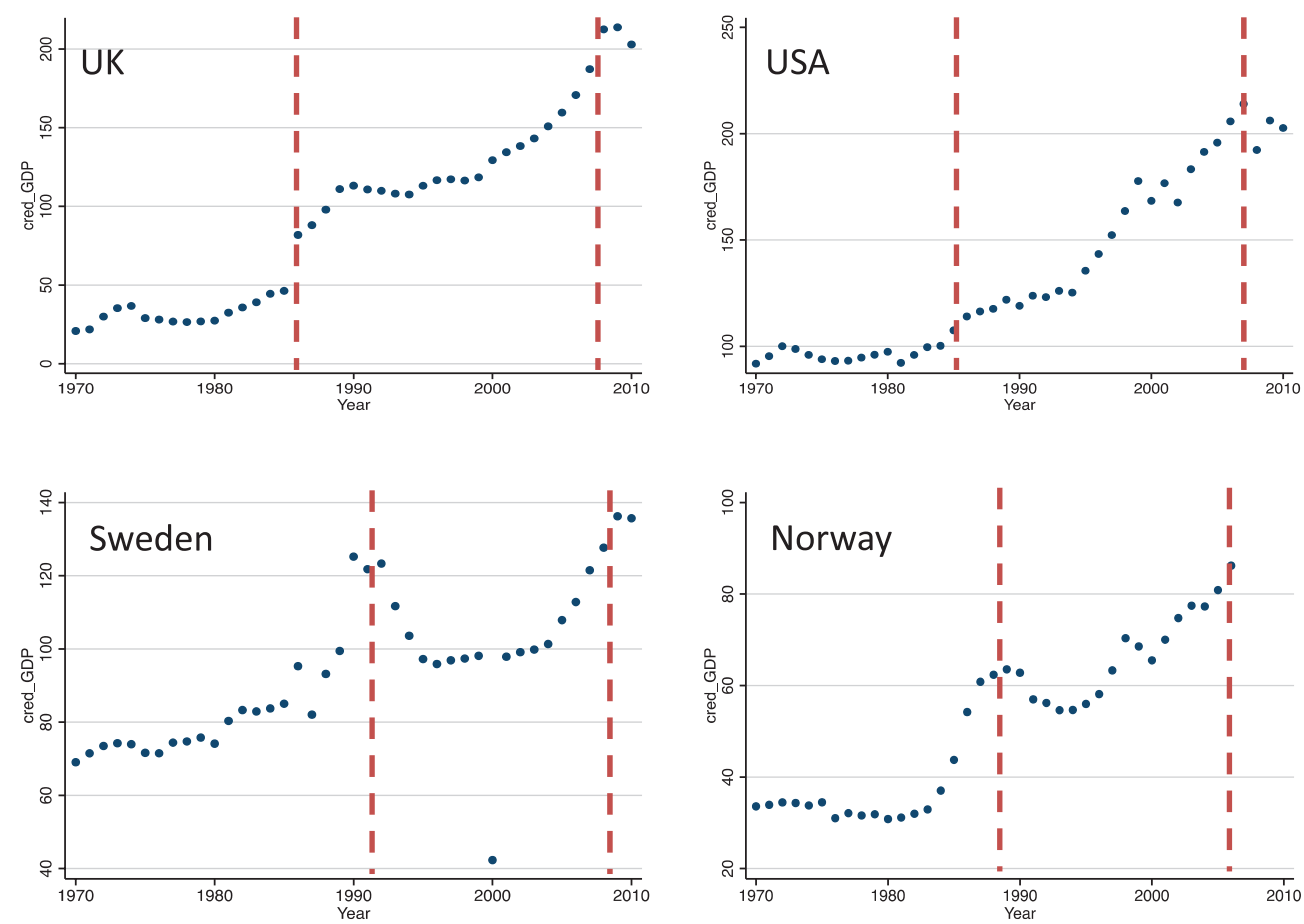

Fig. 1. Private credit to GDP ratio and crises: select countries, 1970-2010.

simple correlation analysis shows preliminary support for the existence of a remarkably strong link between credit expansion and the remaining variables, especially inequality, monetary policy and per capita GDP.

The relationship between broad money supply and the interest rate, although negative and statistically significant, is low, confirming the inability of the interest rate alone to properly depict the monetary policy environment (Elekdag and Wu, 2011). Figure 2, which plots the yearly average of credit to GDP ratio, inequality and financial 


\section{Page 14 of $31 \quad$ C. Perugini, J. Hölscher and S. Collie}

Table 2. Descriptive statistics

\begin{tabular}{lrrrrl}
\hline Variable & \multicolumn{1}{l}{ Mean } & Std Dev. & \multicolumn{1}{l}{ Min. } & \multicolumn{1}{l}{ Max. } & Observations \\
\hline cred_GDP & 87.266 & 44.339 & 12.767 & 227.753 & 670 \\
Ineq(top 1\%) & 7.576 & 2.466 & 3.490 & 18.290 & 531 \\
Dereg (cred mkt) & 8.231 & 1.151 & 4.422 & 10.000 & 684 \\
cap_form_gdp & 22.567 & 3.963 & 15.312 & 36.372 & 673 \\
portf_inv_gdp & -4.335 & 67.516 & -575.262 & 598.181 & 661 \\
M2_gdp & 85.751 & 43.493 & 18.589 & 238.975 & 683 \\
real_int_rate & 4.240 & 3.963 & -13.184 & 19.259 & 676 \\
Real_gdp_growth & 0.027 & 0.022 & -0.076 & 0.110 & 684 \\
pc_gdp (ln) & 9.664 & 0.311 & 8.608 & 10.353 & 684 \\
\hline
\end{tabular}

Table 3. Correlation analysis

\begin{tabular}{|c|c|c|c|c|c|c|c|c|c|}
\hline & $\begin{array}{l}\text { cred_ } \\
\text { GDP }\end{array}$ & $\begin{array}{l}\text { Ineq } \\
\text { (top1) }\end{array}$ & $\begin{array}{l}\text { Dereg } \\
\text { (cred mkt) }\end{array}$ & $\begin{array}{l}\text { cap_form_ } \\
\text { gdp }\end{array}$ & $\begin{array}{l}\text { portf_inv_ } \\
\text { gdp }\end{array}$ & M2_gdp & $\begin{array}{l}\text { real_int_ } \\
\text { rate }\end{array}$ & $\begin{array}{l}\text { pc_gdp } \\
(\ln )\end{array}$ & $\begin{array}{l}\text { Real_gdp_ } \\
\text { growth }\end{array}$ \\
\hline cred_GDP & 1 & & & & & & & & \\
\hline Ineq (top1) & $0.503^{\star}$ & 1 & & & & & & & \\
\hline Dereg (cred mkt) & $0.269^{\star}$ & $0.182^{\star}$ & 1 & & & & & & \\
\hline cap_form_gdp & $-0.110^{\star}$ & $-0.229^{\star}$ & $-0.369^{\star}$ & 1 & & & & & \\
\hline portf_inv_gdp & $-0.078^{\star}$ & 0.060 & -0.046 & $0.091^{\star}$ & 1 & & & & \\
\hline M2_gdp & $0.693^{\star}$ & $0.290^{\star}$ & $-0.079^{\star}$ & $0.073^{\star}$ & -0.032 & 1 & & & \\
\hline real_int_rate & $-0.162^{\star}$ & $-0.109^{\star}$ & $0.226^{\star}$ & $-0.197^{\star}$ & $0.139^{\star}$ & $-0.187^{\star}$ & 1 & & \\
\hline pc_gdp (ln) & $0.583^{\star}$ & $0.374^{\star}$ & $0.578^{\star}$ & $-0.383^{\star}$ & $-0.175^{\star}$ & $0.179^{\star}$ & $0.170^{\star}$ & 1 & \\
\hline real_gdp_growth & $-0.161^{\star}$ & 0.034 & -0.012 & 0.035 & -0.009 & $-0.089^{\star}$ & $-0.150^{\star}$ & $-0.215^{\star}$ & 1 \\
\hline
\end{tabular}

${ }^{\star}$ Significant at the $1 \%$ level or better.

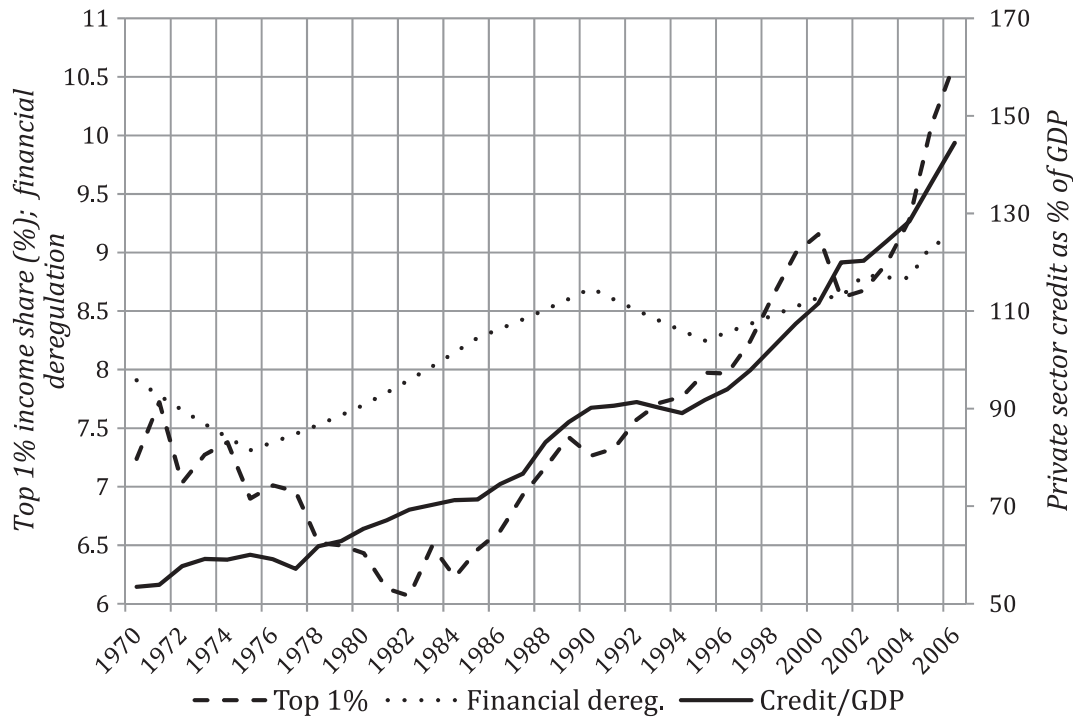

Fig. 2. Private credit, inequality and financial deregulation (mean of 18 OECD countries 1970-2007). 
deregulation for the 18 countries of our sample, also provides preliminary support to the idea of co-movement between the variables of key interest here.

This particularly holds after the turbulent 1970s, following which all three indicators rose sharply during the 1980s before stabilising somewhat in the early half of the 1990s and then growing together once more from the mid-1990s onwards. The relationship between inequality and credit is particularly strong and straightforward for some countries of great interest due to their macroeconomic and financial histories, as illustrated in the diagrams in Figure 3.

Data in Table 3 also reveal that the correlation among the remaining variables used in our empirical model as drivers of credit growth is relatively low. In particular, the weak links between inequality, credit market deregulation and monetary policy variables are of interest here, since they are related to interpretative frameworks emphasising the role of political economy mechanisms (e.g. the hypotheses of Rajan, Stiglitz and Acemoglu). The results of the Granger causality analysis (Granger, 1969), although not conclusive due to their own nature and limitations, ${ }^{3}$ provide evidence of independence of these variables (Table 4 ). In each of the tests, the null hypothesis $\left(\mathrm{H}_{0}\right)$ of deregulation not Grangercausing inequality (as per Acemoglu's conjecture), or of inequality not Granger-causing deregulation (Rajan) and monetary expansion (Stiglitz), cannot be rejected.
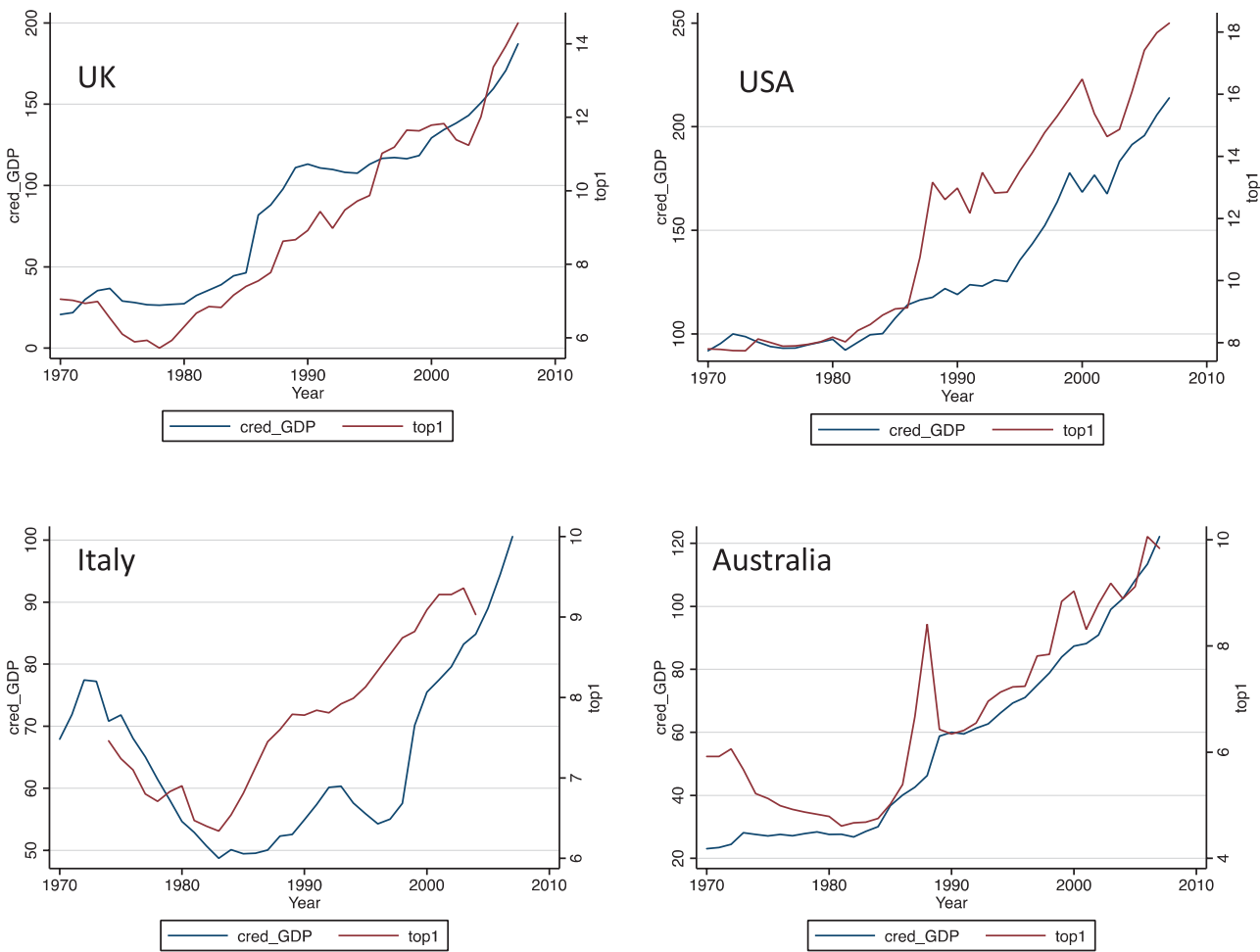

Fig. 3. Private credit to GDP ratio and inequality: select countries, 1970-2010.

3 The Granger causality test is a statistical hypothesis test for determining whether one time series is useful in forecasting another, since causality could be reflected by measuring the ability to predict the future values of a time series using past values of another time series (Granger, 1969). Under such a concept of causality, a time series A is said to Granger-cause B if it can be shown, by means of $F$-tests on lagged values of A (and with lagged values of B also included), that those A values provide statistically significant information about future values of $B$. 
Page 16 of 31 C. Perugini, J. Hölscher and S. Collie

Table 4. Granger causality tests (deregulation/inequality and monetary policy/inequality)

\begin{tabular}{|c|c|c|c|c|c|}
\hline & $\begin{array}{l}\mathrm{H}_{0}: \\
\text { Dereg_cred_mkt does } \\
\text { not Granger-cause } \\
\text { Ineq (top } 1 \% \text { ) }\end{array}$ & $\begin{array}{l}\mathrm{H}_{0} \text { : } \\
\text { Ineq (top 1\%) does } \\
\text { not Granger-cause } \\
\text { Dereg_cred_mkt }\end{array}$ & & $\begin{array}{l}\mathrm{H}_{0} \text { : } \\
\text { Ineq (top 1\%) does } \\
\text { not Granger-cause } \\
\text { M2_gdp }\end{array}$ & \\
\hline & $F$-statistic ( $p$-value) & $\begin{array}{l}F \text {-statistic } \\
(p \text {-value })\end{array}$ & $N$ obs & $\begin{array}{l}F \text {-statistic } \\
\text { (p-value) }\end{array}$ & $N$ obs \\
\hline 1 lag & $1.467(0.226)$ & $0.981(0.322)$ & 487 & $1.387(0.238)$ & 489 \\
\hline 2 lags & $2.794(0.062)$ & $1.570(0.209)$ & 468 & $0.487(0.615)$ & 470 \\
\hline 3 lags & $1.977(0.116)$ & $1.514(0.210)$ & 449 & $0.407(0.748)$ & 451 \\
\hline 4 lags & $1.346(0.251)$ & $1.194(0.313)$ & 430 & $0.341(0.850)$ & 432 \\
\hline 5 lags & $1.591(0.161)$ & $1.802(0.111)$ & 411 & $0.230(0.949)$ & 413 \\
\hline
\end{tabular}

\subsection{Econometric methods and the empirical model}

In order to assess the impact of inequality and deregulation on credit expansion, we consider the following dynamic model:

$$
\begin{aligned}
\text { Cred }_{i, t}= & \alpha_{i}+\tau_{t}+\gamma \text { Cred }_{i, t-1}+\beta_{1} \text { Ineq }_{i, t}+\beta_{2} \text { Dereg }(\text { cred mkt })_{i, t}+\beta_{3} \text { Cap_form } \\
& +\beta_{4} \text { Port_Inv }_{i, t}+\beta_{5} M 2_{i, t}+\beta_{6} \text { Int_rate }_{i, t}+\beta_{7} G D P \_g r_{i, t}+\beta_{8} \text { PCgdp }+\varepsilon_{i, t}
\end{aligned}
$$

where subscripts $i$ and $t$ refer to countries and years, respectively $(i=1, \ldots, 18 ; t=1970$, $\ldots, 2007) ; \alpha_{i}$ and $\tau_{t}$ are the country- and the time-specific effects and $\varepsilon_{i, t}$ the error terms. The acronyms indicate the variables as described in the previous sections. Obviously, the inclusion of country- and time-specific effects is a major advantage of the panel approach, providing controls for unobservable or imperfectly measured drivers of credit, such as global liquidity conditions or foreign capital inflows. Equation (2) is then further extended by introducing an interaction variable obtained by multiplying the indicators of inequality and credit market deregulation, in order to test the possibility that the effect of inequality on credit growth might be enhanced or exist only under laxer regulatory frameworks.

The dynamic specification of equation (2) accounts for the fact that the level of credit to GDP ratio is characterised by high within-country inertia and can be viewed as a time-persistent phenomenon. Not including the lagged dependent variable among the regressors (when significant) would affect the estimation outcomes due to omitted variable bias. In addition, as previously mentioned, equation (2) can be characterised by the presence of other endogenous regressors and reverse causality issues. A large body of literature has analysed the effects of credit on inequality, emphasising how the possibility of undertaking investments in physical and especially human capital may be hampered by the existence of credit constraints ( $\mathrm{Li}$ et al., 1998), credit market imperfections (Galor and Zeira, 1993) and poorly developed financial markets (Greenwood and Jovanovic, 1990). Similar concerns of inverse direction of causality may arise between the size of credit in the economy and the extent of investments, consumption and ultimately aggregate demand (see, e.g., Elekdag and Wu, 2011) and with reference to growth and development driven by financial deepening and increased levels of intermediation (Rajan and Zingales, 1998; Decressin and Terrones, 2011). 
Dealing with all these issues simultaneously is a challenging task. Our choice here is to use different approaches able to address some or all of the problems mentioned and to compare the outcomes, particularly the relationships of interest, step by step. As a first pass, we estimate a standard fixed-effects (FE) model, as in Bordo and Meissner (2012), but employing a panel-corrected standard error (PCSE) model, which allows correction for autocorrelation and heteroscedasticity of errors (which need to be addressed in our estimates) and provides more reliable standard errors (Beck and Katz, 1995). However, the presence of the lagged dependent variable, due to its potential correlation with the composite error $\left(\alpha_{i}+\varepsilon_{i, t}\right)$, may lead to inconsistent parameter estimates also when country heterogeneity is accounted for by means of conventional fixed- or random-effects (RE) estimators (Baltagi, 2001). This is due to the so-called dynamic panel bias-although if $T$ (the time dimension) is sufficiently large, this becomes insignificant. Under such circumstances, a standard, straightforward fixed-effects estimator can be employed (Roodman, 2009). Yet this approach fails to address the problems of endogeneity due to potential reverse causality. To deal with this issue, we adopt two different approaches. The first relies on a fixedeffects instrumental variable estimator based on Hansen's (1982) original generalised method of moments (GMM), which allows the instrumentation of variables at risk of endogeneity as well as providing standard errors robust to heteroscedasticity and autocorrelation. As instruments, we use a mix of internal (up to two lags) and external variables derived from the literature (see the beginning of Section 2) that are expected to impact on inequality, investment and growth and to be uncorrelated with the dependent variable (credit as a percentage of GDP). In particular, in order to account for the labour and product market institutional settings expected to impact on inequality, we employed as instruments variables derived again from the Fraser Institute database, namely: (i) indicator $5 \mathrm{~b}$ (labour market regulation), which includes information on hiring regulations for temporary workers and minimum wage, hiring and firing regulations, centralised collective bargaining, hours regulation, conscription and mandated costs of dismissal; and (ii) indicator 5c (business regulations), with information on price controls, administrative requirements, bureaucracy costs, time and money required to start a business, extra payments/bribes/favouritism, licensing restrictions and cost of tax compliance. To control for the aspects related to globalisation of markets, particularly on the relative demand for skills and hence on relative wages, we used the basic indicator of foreign trade openness and economic integration (total trade-to-GDP ratio) available in the World Development Indicators database. The validity of the instruments is tested by means of the standard tests reported at the bottom of Tables 5, 6 and A1.

As a check for the robustness of the results obtained, we also approach the endogeneity issue using the System GMM estimation techniques (Arellano and Bover, 1995; Blundell and Bond, 1998). The GMM-Sys estimator uses as instruments the lagged values of the endogenous explanatory variables. Variables in levels are instrumented with lagged first differences; then, in order to consider these additional moments as valid instruments for levels, the identifying assumption that past changes of the explanatory variables are uncorrelated with current errors in levels, which include fixed effects, is required (Roodman, 2009). The validity of the moment conditions can be tested by means of the test of overidentifying restrictions proposed by Sargan (1958) and Hansen (1982) and by testing the null hypothesis of no second order serial correlation in the error term. 


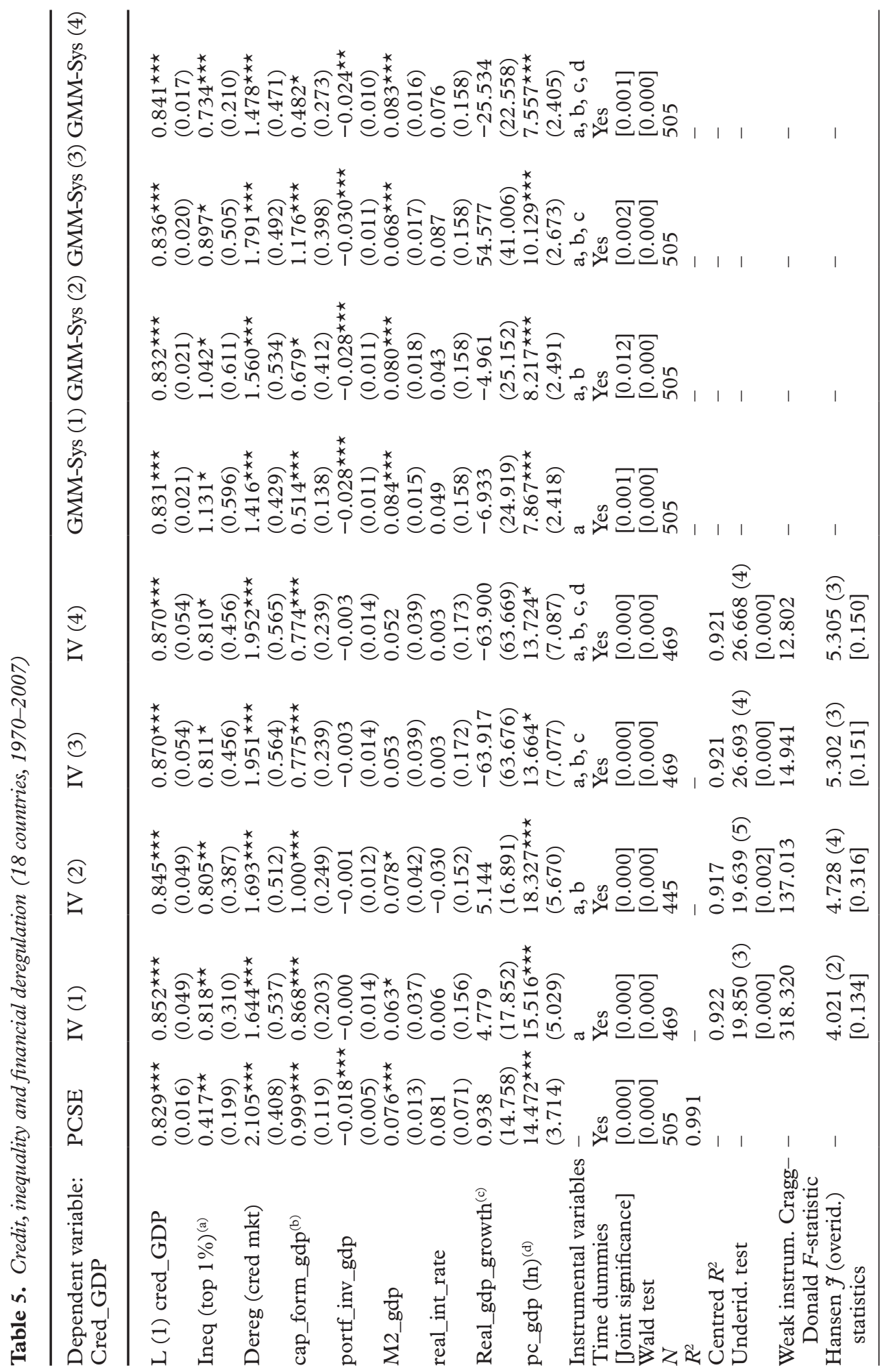




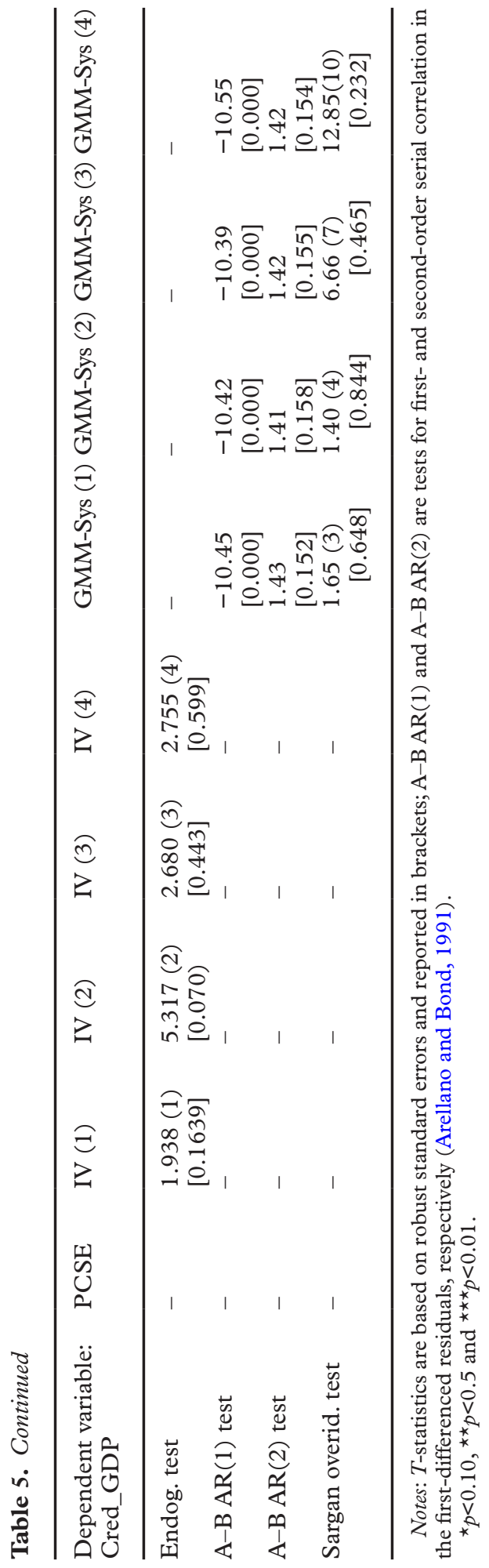




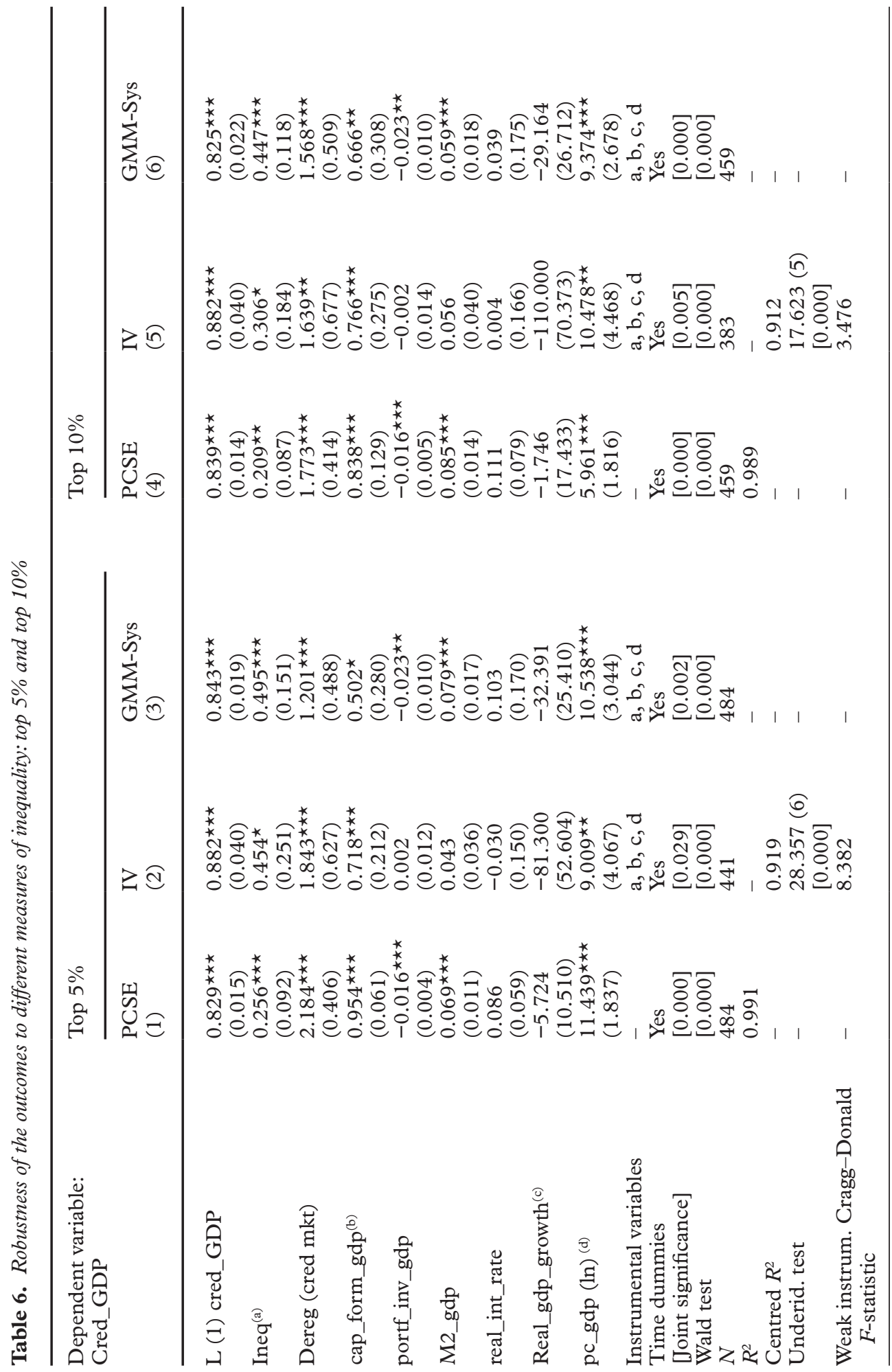




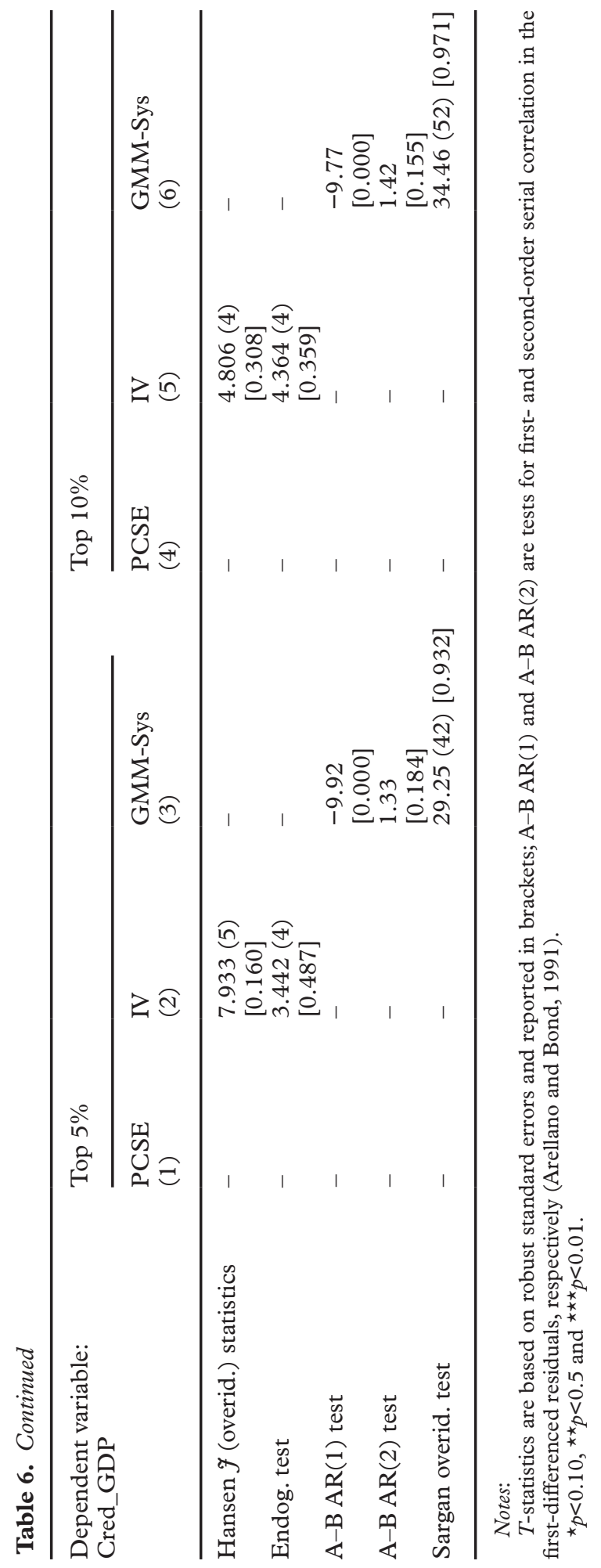




\section{Page 22 of 31 C. Perugini, J. Hölscher and S. Collie}

The GMM-Sys estimator has the advantage of allowing instrumentation of endogenous variables with internal lags; however, it is designed for large $N$, small $T$ panels to deal efficiently with dynamic panel bias. Its employment in dataset like the current one (large $T$, small $N$ ) may cause a natural proliferation of the number of instruments (Roodman, 2009; Bowsher, 2002). However, System GMM estimation allows some flexibility by means of several specification choices. In particular, given the structure of our panel, we use the one-step estimator and correct the standard errors to account for small-sample bias and heteroscedasticity by applying the Huber-White robust variance estimator. Furthermore, to address the problem of instrument proliferation, we use a combined strategy obtained by collapsing instruments (i.e. creating one instrument for each variable and lag distance only, with 0 substituted for any missing values) and restricting the number of lags used as instruments.

\subsection{Results}

Table 5 reports the estimates of our empirical model, which firstly highlight an overall stability across the alternative econometric approaches. The coefficient of the lagged dependent variable is always positive and significant, confirming the validity and the necessity of a dynamic specification. Conceptually, this evidence can be explained not only with the obvious effects of borrowing decisions made years before, but also in terms of herd behaviour, as explained by Rajan (1994). The fact that others are lending may be considered valuable information concerning the creditworthiness of a potential borrower. More importantly, performance being generally assessed relative to some market benchmark, managers from financial institutions have a strong incentive to behave as their peers, providing inertia to credit expansion over time (Gosh, 2010).

As for the other control variables, capital formation emerges as positively related to credit, confirming the long and extensive literature arguing that capital investments (especially those driven by technological breakthroughs and displacement) need to be financed with credit (Fisher, 1933; Minsky, 1986). Also, as expected, larger money availability (M2-to-GDP ratio) drives credit expansion (Elekdag and Han, 2012; Elekdag and Wu, 2011); similarly, more advanced levels of development (per capita GDP) are positively associated with higher credit. The size of portfolio investments, which also include external liabilities and should control for capital inflows, is either not significant or negative, indicating, as per Mendoza and Terrones (2008), that credit expansion is lower in the presence of large outflows of portfolio investments. The remaining control variables (real interest rate and GDP growth) are not significant. All results are robust to the adoption of IV approaches, which allows for potential endogeneity of explanatory variables.

In all specifications the proxy for financial market liberalisation is found to have a positive, statistically significant (at a more than $99 \%$ confidence level) effect on private sector credit, firmly justifying its inclusion in the model and indicating that its exclusion would certainly lead to omitted variable bias. This evidence is consistent with the conceptual explanations provided by the literature (see, e.g., Gosh, 2010; Dell'Ariccia and Marquez, 2006; Gourinchas et al., 2001) and well-established empirical findings (see, e.g., Mendoza and Terrones, 2008).

As far as the focus of our analysis is concerned, the coefficient of the inequality variable (top $1 \%$ ) is positive and significant in all estimates, suggesting that higher inequality directly (i.e. without any intermediate mechanism) drives higher credit, once its conventional determinants are controlled for. This is in line with the reasoning of Kumhof 
and Rancière (2010) and Kumhof et al. (2012), which we developed in terms of relative income (Duesenberry, 1949; Barba and Pivetti, 2009) and expenditure cascade (Frank et al., 2010) hypotheses. Therefore we found clear cross-country evidence that inequality can directly impact on credit expansion.

Generally speaking, a major concern when studying the effects of inequality is the dependence of outcomes on the specific measure of inequality employed (Litchfield, 1999). In order to assess the robustness of the effects of inequality on the size of credit, we carried out additional estimations using the income share held by the top $5 \%$ and top $10 \%$ of the distribution. The results are reported in Table 6 and confirm that higher inequality triggers higher credit-to-income ratios; similarly, the signs and significance of the remaining variables remain virtually unchanged.

Although the literature explored here envisages direct and independent relationships between credit expansion and inequality on the one side and financial deregulation on the other, other recent contributions tend to hypothesise a joint, self-reinforcing interaction effect. Tridico (2012), for example, states that the rise of inequality generated on the labour market led to an increased demand of credit, which translated into a credit expansion due to the increase of supply fed by lax monetary policies and financial deregulation. This would suggest that the effect of inequality on credit expansion should be magnified by deregulation. Translated into empirical terms, the interaction term between the metric of inequality and deregulation should be positive and significant in the estimates. Estimation of the models with the inclusion of this interaction effect (columns 1-3 of Table A1 in the Appendix) does not provide support to the possibility that inequality may further foster credit expansion in the presence of less regulated institutional settings. On the contrary, the interaction terms render the main effects insignificant: they do not add any information to the model, while producing only disturbance due to redundant information. In columns $4-6$ of Table A1, we test the possibility that this effect might be confined only to countries with very high levels of deregulation. To this aim, the interaction term is generated by multiplying the inequality indicator and a dummy variable that is 1 if the corresponding level of deregulation is in the top decile of its distribution and 0 otherwise. This sorts out the issues of multicollinearity (the main effects regain significance), but the coefficient of the interaction term is again not statistically different from zero. This means that while there is a direct effect of inequality on credit (and of deregulation on credit), it is not magnified by deregulation. Therefore it seems that the two effects acted separately on credit expansion, without self-reinforcing patterns.

\section{Discussion and final remarks}

The principle aim of this research was to provide new evidence on the relationship between the distribution of income and financial stability. Whilst the existing literature offers a number of diverse theoretical explanations as to how the former might impact on the latter, they all have in common the notion that widening income inequality impacts negatively on household balance sheets. Accordingly, the primary focus of our empirical investigation was to test whether a causal link exists between widening inequality and household indebtedness. This was done via econometric analysis employing a panel of data from 18 OECD countries over the period 1970-2007, the findings of which support the existence of a positive relationship between the proportion of national income accruing to the top percentiles of the income distribution and the ratio 


\section{Page 24 of 31 C. Perugini, J. Hölscher and S. Collie}

of private sector credit to GDP ratio. In a secondary exercise, the latter is found to be a significant predictor of systemic financial risk within our sample.

Our findings contrast with those of the preceding literature, in particular those reported by Bordo and Meissner (2012), who concluded against an income inequalitydebt nexus and whose research served as an inspiration for our own. Our findings suggest that this evidence can be considered far from conclusive. However, a few important features of the methodology employed here set our research apart.

First, our methodology focuses on the effects of the level of income inequality on the level of indebtedness (and hence financial risk) whereas $\mathrm{B} \& \mathrm{M}$ focus on changes in these variables. Their findings are thus silent on the effects of absolute levels of income inequality and debt; yet, for reasons stated above, a focus on levels is conceptually superior given the relationships under investigation.

Second, our methodology takes account of a key institutional determinant of credit availability - which is emphasised in the literature on credit booms, but which B\&M ignore entirely - namely the extent to which credit markets are regulated. We find this to be a highly significant predictor of credit (as a percentage of GDP) and its omission would undoubtedly bias the results of any such an analysis. Furthermore, we argue that the credit measure we use as the dependent variable in our empirical model is more appropriate where financial fragility is concerned (e.g. it includes lending to the private sector from non-bank financial institutions - an increasingly large source of credit in most advanced economies - which is not accounted for in the bank credit variable employed by B\&M).

Finally, we employ econometric methods that enable us to control for issues relating to possible endogeneity and interdependence of the explanatory variables in our empirical model identified in the credit literature, which $B \& M$ make no attempt to account for.

As a result of the above methodological differences, we argue that the findings presented here more accurately reflect the true nature of the inequality-debt-crisis relationship; therefore the existence of a relationship between inequality and credit expansion (and therefore crisis) cannot be ruled out.

We are aware of the limitations of the results obtained in such a methodological framework, which does not allow us to model explicitly (but only to account for) specific historical and social factors. Further analyses dealing with these aspects, under a different methodological perspective, are therefore needed to complement our evidence. In terms of framing our findings in the context of the current theoretical debate over the inequality-debt transmission mechanism, our findings, if confirmed, support the notion of a direct causal link between income inequality and indebtedness. This would be consistent with the models of Kumhof and Rancière (2010) and Kumhof et al. (2012) and in line with theories of consumer behaviour based on the relative income hypothesis (Duesenberry, 1949) and expenditure cascades (Frank et al., 2010). With regard to Rajan's hypothesis of widening income inequality in the USA leading to increased pressure to deregulate financial markets, we find no empirical evidence of this mechanism on a cross-country basis. In fact our findings suggest that income inequality drives private sector indebtedness irrespective of the level of financial regulation (and vice versa). Nor do we find empirical support for the notion that rising inequality prompts looser monetary policy (as per Stiglitz, 2012; Fitoussi and Saraceno, 2011). Having said all of this, these explanations would benefit from further investigation since, as emphasised by Van Treek (2014), they may be complementary rather than mutually exclusive. 
The implications of a direct causal relationship link between income inequality and debt and thus systemic financial risk, if confirmed, would not be small. For the economics profession, the view that the distribution of permanent income is irrelevant to macroeconomic outcomes (the conventional wisdom in mainstream economics in the decades preceding the crisis) at the very least needs review. This ideology has its foundations in permanent-income and life-cycle hypotheses of consumer behaviour, which have long sat uncomfortably with real-world data. These foundations are increasingly shown to be shaky, putting the entire edifice at risk. We join others in arguing for a renaissance of the relative income hypothesis, which has the potential to offer greater insights into real-world consumer behaviour. For policy makers wishing to make the financial system more robust, the evidence presented here suggests that they may need to cast the net wider than regulatory reforms and monetary policy and consider the impact of the distribution of income on household indebtedness.

\section{Bibliography}

Abiad, A., Detragiache, E. and Tressel, T. 2008. 'A New Database of Financial Reforms', Working Paper no. WP/08/266, International Monetary Fund

Acemoglu, D. 2011. Thoughts on Inequality and the Financial Crisis, http://economics.mit.edu/ files/6348 [date last accessed: 7 November 2013]

Adarov, A. and Tchaidze, R. 2011. 'Development of Financial Markets in Central Europe: The Case of the CE4 Countries', Working Paper no. WP/11/101, International Monetary Fund

Arellano, M. and Bond, S. 1991. Some tests of specification for panel data: Monte Carlo evidence and an application to employment equations. The Review of Economic Studies, vol. 58, 277-97

Arellano, M. and Bover, O. 1995. Another look at the instrumental variable estimation of errorcomponents models, fournal of Econometrics, vol. 68, no. 1, 29-51

Atkinson, A. and Morelli, S. 2010. Inequality and Banking Crises: A First Look, paper prepared for the European Labour Forum, Turin, organised by the International Training Centre of the International Labour Organization

Atkinson, A. and Morelli, S. 2011. 'Economic Crises and Inequality', Human Development Research Paper no. HDRP-2011-06, Human Development Report Office, United Nations Development Programme

Atkinson, A. B., Piketty, T. and Saez, E. 2011. Top incomes in the long run of history, fournal of Economic Literature, vol. 49, no. 1, 3-71

Autor, D. H. and Katz, L. F. 1999. Changes in the wage structure and earnings inequality, pp. 1463-555 in Ashenfelter, O. and Card, D. (eds), Handbook of Labor Economics, vol. 3A, Amsterdam, Elsevier

Autor, D. H., Levy, F. and Murnane, R. J. 2003. The skill-content of recent technological change: an empirical investigation, Quarterly fournal of Economics, vol. 118, no. 4, 1279-333

Azzimonti, M., de Francisco, E. and Quadrini, V. 2012. 'Financial Globalization, Inequality, and the Raising of Public Debt', CEPR Discussion Paper no. 8893

Baltagi, B. H., 2001. Econometric Analysis of Panel Data, 2nd edn, Chichester, Wiley

Barba, A. and Pivetti. M. 2009. Rising household debt: its causes and macroeconomic implications-a long-period analysis, Cambridge fournal of Economics, vol. 33, no. 1, 113-37

Bartels, L. 2008. Unequal Democracy: The Political Economy of the New Gilded Age, New York, Russell Sage Foundation

Beck, N. and Katz, J. N. 1995. What to do (and not do) with time-series cross-section data, American Political Science Review, vol. 89, no. 3, 634-47

Becker, G. J. 1964. Human Capital: A Theoretical and Empirical Analysis, with Special Reference to Education, Chicago, University of Chicago Press

Bernanke, B., Gertler, M. and Gilchrist, M. 1999. The financial accelerator in and quantitative business cycle framework, pp. 1531-614 in Taylor, J. and Woodford, M. (eds), Handbook of Macroeconomics, vol. 1C, Amsterdam, North-Holland

Bertrand, M. and Morse, A. 2013. 'Trickle-down Consumption', NBERWorking Paper no. 18883 


\section{Page 26 of 31 C. Perugini, J. Hölscher and S. Collie}

Blundell, R. and Bond, S. 1998. Initial conditions and moment restrictions in dynamic panel data model, fournal of Econometrics, vol. 87, no. 1, 115-43

Blundell, R. and Etheridge, B. 2010. Consumption, income and earnings inequality in Britain, Review of Economic Dynamics, vol. 13, no. 1, 76-102

Blundell, R., Pistaferri, L. and Preston, I. 2008. Consumption inequality and partial insurance, American Economic Review, vol. 98, no. 5, 1887-921

Bordo, M. D. and Meissner, C. M. 2012. Does inequality lead to a financial crisis? fournal of International Money and Finance, vol. 31, no. 8, 2147-61

Borio, C., Furfine, C. and Lowe, P. 2001. 'Procyclicality of Financial Systems and Financial Stability: Issues and Policy Options', BIS Paper no. 1, Bank for International Settlements, Basel

Borio, C. and White, W. R. 2003. Whither monetary and financial stability: the implications of evolving policy regimes, Proceedings - Economic Policy Symposiom - Fackson Hole, Federal Reserve Bank of Kansas City, 131-211

Bowsher, C. G. 2002. On testing overidentifying restrictions in dynamic panel data models, Economics Letters, vol. 77, no. 2, 211-20

Brzozowski, M., Gervais, M., Klein, P. and Suzuki, M. 2010. Consumption, income, and wealth inequality in Canada, Review of Economic Dynamics, vol. 13, no. 1, 52-75

Card, D. and Di Nardo, J. E. 2002. Skill-based technological change and rising wage inequality: some problems and puzzles, fournal of Labor Economics, vol. 20, no. 4, 733-83

Card, D., Lemieux, T. and Craig Riddell, W. 2004. Unions and wage inequality, fournal of Labor Research, vol. 25, no. 4, 519-62

Castellani, D., Serti, F. and Tomasi, C. 2010. Firms in international trade: importers' and exporters' heterogeneity in Italian manufacturing industry, World Economy, vol. 33, no. 3, 424-57

Chusseau, N., Dumont, M. and Hellier, J. 2008. Explaining rising inequality: skill-biased technical change and North-South trade, fournal of Economic Surveys, vol. 22, no. 3, 409-57

Corsetti, C., Pesenti, P. and Roubini, N. 1999. What caused the Asian currency and financial crisis? Fapan and the World Economy, vol. 11, no. 3, 305-73

Cottarelli, C. and Kourelis, A. 1994. 'Financial Structure, Bank Lending Rates, and the Transmission Mechanism of Monetary Policy', Working Paper no. 94/39, International Monetary Fund

Dawson, J. D. 2006. Regulation, investment, and growth across countries, CATO fournal, vol. 26, no. 3, 489-509

Debacker, J., Heim, B., Panousi, V., Ramnath, S. and Vidangos, I. 2013. Rising inequality: transitory or persistent? New evidence from a panel of US tax returns, Brookings Papers on Economic Activity, 67-142

Decressin, J. and Terrones, M. 2011. Credit boom-bust cycles: their triggers and policy implications, in World Economic Outlook, October 2011: Slowing Growth, Rising Risks, World Economic and Financial Surveys, Washington, DC, International Monetary Fund

Dell'Ariccia, G. and Marquez, R. 2006. Lending booms and lending standards, fournal of Finance, vol. 51, no. 5, 2511-46

Demirguc-Kunt, A. and Detragiache, E. 1998. 'Financial Liberalization and Financial Fragility', Working Paper no. 98/83, International Monetary Fund

Duesenberry, J. 1949. Income, Saving and the Theory of Consumer Behaviour, Cambridge, MA, Harvard University Press

Dynan, K.,Skinner, J. and Zeldes, S. 2004. Do the rich save more? Fournal of Political Economy, vol. 112, no. 2, 397-444

Elekdag, S. and Han, F. 2012. 'What Drives Credit Growth in Emerging Asia?' Working Paper no. 12/43, International Monetary Fund

Elekdag, S. and Wu, Y. 2011. 'Rapid Credit Growth: Boon or Boom-Bust?' Working Paper no. 11/241, International Monetary Fund

European Central Bank. 2009. Recent developments in the retail bank interest rate pass-through in the euro area, Monthly Bulletin, August, 93-105

Fallah, B. and Partridge, M. D. 2006. The elusive inequality-economic growth relationship: are there differences between cities and the countryside? Annals of Regional Science, vol. 41, no. 2, 375-400

Feenstra, R. C. and Hanson, G. H. 1996. Globalization, outsourcing, and wage inequality, American Economic Review, vol. 86, no. 2, 240-5 
Fisher, I. 1932. Booms and Depressions, New York, Adelphi

Fisher, I. 1933. The debt-deflation theory of great depressions, Econometrica, vol. 1, no. 4, 337-57

Fitoussi, J. and Saraceno, R. 2010. Europe: how deep is a crisis? Policy responses and structural factors behind diverging performances, fournal of Globalization and Development, vol. 1, no. 1, article 17

Fitoussi, J. and Saraceno, R. 2011. Inequality, the crisis and after, Rivista di Politica Economica, vol. 100, nos $1-3,9-27$

Frank, R. H., Levine, A. S. and Dijk, O. 2010. Expenditure Cascades, http://ssrn.com/ abstract $=1690612$ [date last accessed: 7 November 2013]

Friedman, M. 1957. A Theory of the Consumption Function, Princeton, Princeton University Press

Fujita, M., Krugman, P. and Venables, A. J. 1999. The Spatial Economy, Cambridge, MA, MIT Press

Galbraith, J. K. 1992 [1954]. The Great Crash, 1929, London, Penguin

Galbraith, J. K. 2007. Global inequality and global macroeconomics, fournal of Policy Modelling, vol. 29 , no. $4,587-607$

Galbraith, J. K. 2012. Inequality and Instability: A Study of the World Economy fust Before the Great Crisis, Oxford, Oxford University Press

Galor, O. and Zeira, J. 1993. Income distribution and macroeconomics, Review of Economic Studies, vol. 60 , no. $1,35-52$

Giannone, D., Lenza, M. and Reichlin, L. 2011. Market freedom and the global recession, IMF Economic Review, vol. 59, no. 1, 111-35

Gilens, M. 2005. Inequality and democratic responsiveness, Public Opinion Quarterly, vol. 69, no. $5,778-896$

Goos, M. and Manning, A. 2007. Lousy and lovely jobs: the rising polarization of work in Britain, Review of Economics and Statistics, vol. 89 (February), 118-33

Gosh, S. 2010. Credit growth, bank soundness and financial fragility: evidence from Indian banking sector, South Asia Economic fournal, vol. 11, no. 1, 69-98

Gourinchas P., Valdes, R. and Landerretche, O. 2001. 'Lending Booms: Latin America and the World', NBER Working Paper no. 8249

Granger, C. W. J. 1969. Investigating causal relations by econometric models and cross-spectral methods, Econometrica, vol. 37, no. 3, 424-38

Greenwood, J. and Jovanovic, B. 1990. Financial development, growth, and the distribution of income, fournal of Political Economy, vol. 98, no. 4, 942-63

Gwartney, J., Lawson, R., Grubel, H., de Haan, J., Sturm, J. and Zandberg, E. 2010. Economic Freedom of the World: 2009 Annual Report, Vancouver, Fraser Institute, http://www.freetheworld. com/2009/reports/world/EFW2009_toc_exsum.pdf

Hansen, L. P. 1982. Large sample properties of generalized method of moments estimators, Econometrica, vol. 50, 1029-54

Iacoviello, M. 2008. Household debt and income inequality, 1963-2003, fournal of Money, Credit and Banking, vol. 40, no. 5, 929-65

IMF-ILO. 2010. The Challenges of Growth, Employment and Social Cohesion, discussion document, Joint International Labour Organization and International Monetary Fund Conference, Oslo, 13 September

Jappelli, T. and Pistaferri, L. 2009. Does consumption inequality track income inequality in Italy? Review of Economic Dynamics, vol. 13, no. 1, 133-53

Kaldor, N. 1955. Alternative theories of distribution, Review of Economic Studies, vol. 23, no. 2, 83-100

Kalecki, M. 1942. A theory of profit, Economic fournal, vol. 52, 258-66

Kaminsky, G. L. and Reinhart, C. M. 1999. The twin crises: the causes of banking and balanceof-payments problems, American Economic Review, vol. 89, no. 3, 473-500

Kindleberger, C. P. 1978. Manias, Panics, and Crashes: A History of Financial Crisis, New York, Basic Books

Kiyotaki, N. and Moore, J. 1997. Credit cycles, fournal of Political Economy, vol. 105, no. 2, 211-48

Kopczuk, W., Saez, E. and Song, J. 2010. Earnings inequality and mobility in the United States: evidence from social security data since 1937, Quarterly fournal of Economics, vol. 125, no. 1, 91-128 


\section{Page 28 of $31 \quad$ C. Perugini, J. Hölscher and S. Collie}

Krueger, A. 2012. The Rise and Consequences of Inequality in the United States, presentation at the Center for American Progress, Washington, DC, 12 January 2012, http://www.whitehouse.gov/ sites/default/files/krueger_cap_speech_final_remarks.pdf [date last accessed: November 2014]

Krueger, D. and Perri, F. 2006. Does income inequality lead to consumption inequality? Evidence and theory, Review of Economic Studies, vol. 73, no. 1, 163-93

Krugman, P. 2012. End This Depression Now, New York, W. W. Norton

Kumhof, M., Lebarz, C., Rancière, R., Richter, A. W. and Throckmorton, N. A. 2012. 'Income Inequality and Current Account Imbalances', Working Paper no. 12/08, International Monetary Fund

Kumhof, M. and Rancière, R. 2010. 'Inequality, Leverage and Crises', Working Paper no. 10/268, International Monetary Fund

Laeven, L. and Valencia, F. 2013. Systemic banking crises database, IMF Economic Review, vol. $61,225-70$

Leigh, A. 2007. How closely do top incomes shares track other measures of inequality? Economic fournal, vol. 117, 619-33

Lemieux, T. 2006. Increasing residual wage inequality: composition effects, noisy data, or rising demand for skill? American Economic Review, vol. 96, no. 3, 461-98

Lemieux, T. MacLeod,W. B. and Parent, D. 2009. Performance pay and wage inequality, Quarterly fournal of Economics, vol. 124, no. 1, 1-49

Levine, R. 2005. Finance and growth: theory and evidence, in Aghion, P. and Durlauf, S. (eds), Handbook of Economic Growth, 865-934, Amsterdam, Elsevier Science

Li, H., Squire, L. and Zou, H. 1998. Explaining international and intertemporal variations in income inequality, Economic fournal, vol. 108, no. 446, 26-43

Litchfield, J. A. 1999. Inequality: Methods and Tools, http://siteresources.worldbank.org/INTPGI/ Resources/Inequality/litchfie.pdf [date last accessed: 7 November 2013]

Lorenzoni, G. 2005. 'Inefficient Credit Booms', Department of Economics (online), Massachusetts Institute of Technology

Melitz, M. 2008. International trade and heterogeneous firms, in New Palgrave Dictionary of Economics, 2nd edn, Palgrave Macmillan

Mendoza, E. G. and Terrones, M. 2008. 'An Anatomy of Credit Booms: Evidence from the Macro Aggregates and Micro Data', NBER Working Paper no. 14049

Milanovic, B. 2009. Two views on the cause of the global crisis - part I, Yale Global Online, http:// yaleglobal.yale.edu/content/two-views-global-crisis [date last accessed: 7 November 2013]

Milanovic, B. 2010. The Haves and the Have-nots: A Brief and Idiosyncratic History of Global Inequality, New York, Basic Books

Minsky, H. P. 1975. fohn Maynard Keynes, New York, McGraw-Hill Professional

Minsky, H. P. 1982. Can 'It' Happen Again? Essays on Instability and Finance, Armonk, M. E. Sharpe

Minsky, H. P. 1986. Stabilizing an Unstable Economy, New York, McGraw-Hill Professional

Modigliani, F. and Brumberg, R. 1954. Utility analysis and the consumption function: an interpretation of cross-section data, pp. 388-436 in Kurihara, K. K. (ed.), Post-Keynesian Economics, New Brunswick, Rutgers University Press

OECD. 2011. Divided We Stand:Why Inequality Keeps on Rising, Paris, OECD Publishing

Palley, T. 2012. From Financial Crisis to Stagnation:The Destruction of Shared Prosperity and the Role of Economics, Cambridge, UK, Cambridge University Press

Piketty, T. 2001. 'Income Inequality in France 1901-98', CEPR Discussion Paper no. 2876

Rajan, R. 1994. Why bank credit policies fluctuate: a theory and some evidence, Quarterly fournal of Economics, vol. 109, 399-441

Rajan, R. G. 2010. Fault Lines, Princeton, Princeton University Press

Rajan, R. G. and Zingales, L. 1998. Financial dependence and growth, American Economic Review, vol. 88, no. 3, 559-86

Rancière, R., Tornell, A. and Westermann, F. 2006. 'Decomposing the Effects of Financial Liberalization: Crises vs. Growth', Working Paper no. 74, Institut für Empirische Wirtschaftsforschung

Reich, R. 2010. Aftershock: The Next Economy and America's Future, New York, Knopf

Reinhart, C. M. and Rogoff, K. S. 2008. Is the US financial crisis so different? An international historical comparison, American Economic Review, vol. 98, 334-9

Roodman, D. 2009. How to do xtabond2: an introduction to difference and system GMM in Stata, Stata fournal, vol. 9, no. 1, 86-136 
Rosen, S. 1981. The economics of superstars, American Economic Review, vol. 71, no. 5, 845-58

Roubini, N. 2011. The Instability of Inequality, http://www.project-syndicate.org/commentary/theinstability-of-inequality [date last accessed: 7 November 2013]

Sargan, D. J. 1958. The estimation of economic relationships using instrumental variables, Econometrica, vol. 26, 393-415

Schularick, M. and Taylor A. M. 2012. Credit booms gone bust: monetary policy, leverage cycles, and financial crises, 1870-2008, American Economic Review, vol. 102, no. 2, 1029-61

Serti, F., Tomasi, C. and Zanfei, A. 2010. Who trades with whom? Exploring the links between firms' international activities, skills, and wages, Review of International Economics, vol. 18, no. $5,951-71$

Spence, A. M. 1974. Market Signaling: Informational Transfer in Hiring and Related Screening Processes, Cambridge, MA, Harvard University Press

Stankov, P. 2012. Cross-country Differences in Credit Market Liberalization Reform Outcomes, http:// ssrn.com/abstract $=1991790$

Stiglitz, J. 2009. The global crisis, social protection and jobs, International Labour Review, vol. 148, nos $1-2,1-13$

Stiglitz, J. E. 2012. The Price of Inequality: How Today's Divided Society Endangers Our Future, Princeton, W. W. Norton

Tridico, P. 2012. Financial crisis and global imbalances: its labour market origins and the aftermath, Cambridge fournal of Economics, vol. 36, no. 1, 17-42

Van Reenen, J. 2011. Wage inequality, technology and trade: 21 st century evidence, Labour Economics, vol. 18, no. 6, 730-41

Van Treek, T. 2014. Did inequality cause the US financial crisis, fournal of Economic Surveys, vol. 28 , no. 3, 421-48

Wade, R. 2010. The great slump: what comes next? Economic E Political Weekly, vol. 45, no. 47, $54-62$

Weiss, A. 1995. Human capital vs. signalling explanations of wages, fournal of Economic Perspectives, vol. 9 , no. 4, 133-54

World Bank. 2012. 2012 World Development Indicators, Washington, DC, The World Bank 


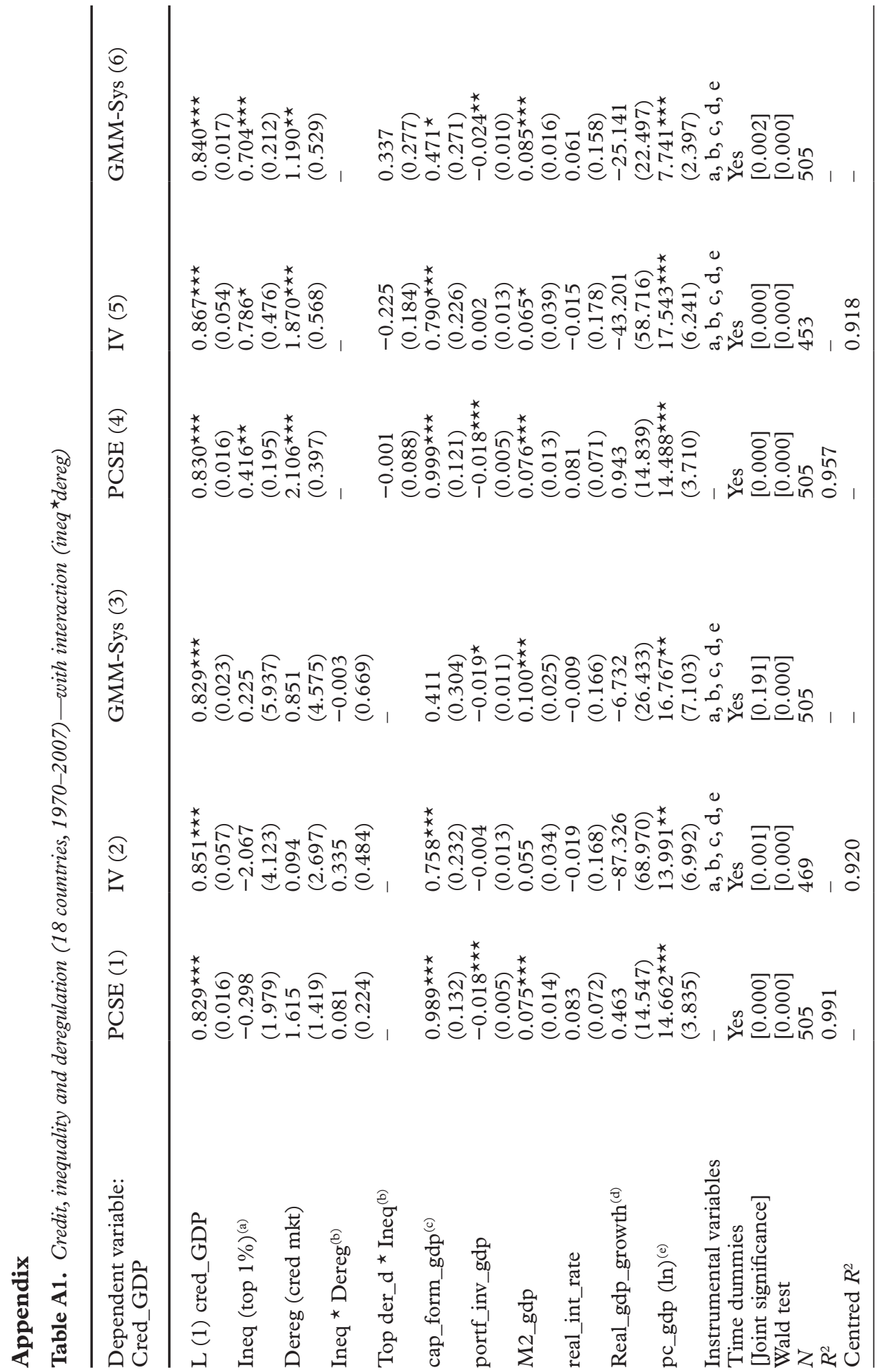




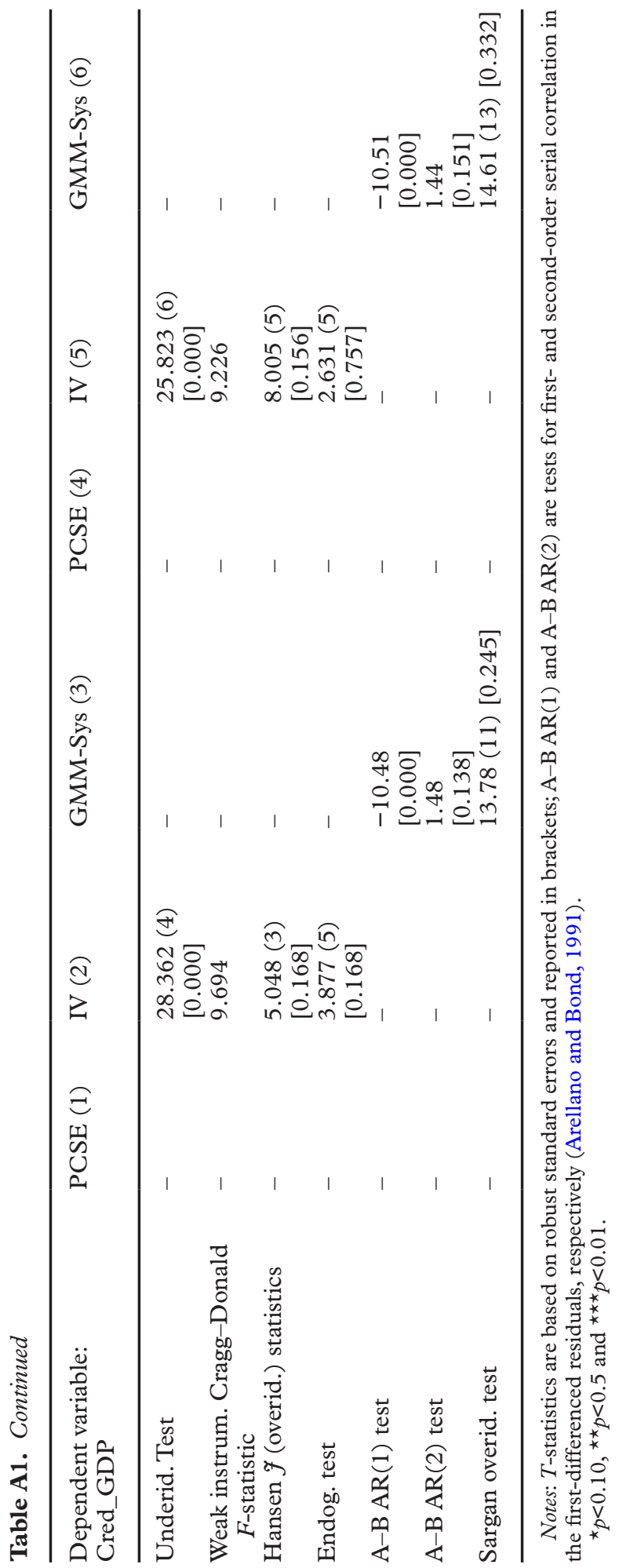

